\title{
ANATOMY AND SEQUENCE ARCHITECTURE OF THE EARLY POST-RIFT IN THE NEUQUÉN BASIN (ARGENTINA): A RESPONSE TO PHYSIOGRAPHY AND RELATIVE SEA-LEVEL CHANGES
}

\author{
GONZALO D. VEIGA, ${ }^{1}$ ERNESTO SCHWARZ, ${ }^{1}$ LUIS A. SPALLETTI, ${ }^{1}$ AND JOSÉ L. MASSAFERRO ${ }^{2}$ \\ ${ }^{1}$ Centro de Investigaciones Geológicas, Universidad Nacional de La Plata-CONICET, Calle 1, \#644, B1900TAC, La Plata, Argentina \\ ${ }^{2}$ YPF S.A. Macacha Güemes 515, C.A. de Buenos Aires, Argentina
}

\begin{abstract}
A detailed architectural and sequence stratigraphic analysis was carried out in the early-post-rift succession of central Neuquén Basin (Middle Jurassic Cuyo Group), integrating outcrop and subsurface information from a $3,000 \mathbf{~ k m}^{2}$ area. Sedimentary facies analysis allowed the definition of six marine facies associations, which are grouped in two main depositional systems. During the late Toarcian to early Bathonian a storm- and wave-dominated shoreface to offshore system was developed. This is overlain by a late Bathonian-early Callovian fluvio-deltaic depositional system.

The sequence stratigraphic analysis of this succession identified parasequences limited by marine flooding surfaces with little evidence of erosion. Parasequences could be grouped into four parasequence sets that show the evolution of the depositional systems and can be interpreted in terms of shoreline trajectories. In this sense, a log-term transgressive event defined by a complicated retrogradational stacking pattern and spanning for almost $10 \mathrm{My}$ is identified for the older deposits. This succession is eventually replaced by a progradational unit that represents highstand conditions. The Cuyo succession identified in this part of the basin is completed by the development of a regressive surface and the onset of a deltaic depositional system with no parasequence development but indicating an abrupt basinward facies shift.

The long-term transgression that dominates the early post-rift succession in this part of the basin is interpreted to represent a period of sustained accommodation creation produced by the combination of thermal subsidence, differential compaction of syn-rift deposits, and eustatic rise under a relatively low sediment supply. Changes in the stacking pattern of retrogradational parasequence sets are thought to be produced by changes in the bathymetry of the topography being flooded, which is a relic of a complex array of footwalls and shoulders generated during the syn-rift stage. Regional changes in thickness and timing for the early post-rift succession could be therefore the result of the relatively passive infill of an inherited topography of the syn-rift, suggesting that most of the accommodation was already created before the onset of the long-term transgressive trend that characterizes the post-rift succession in this part of the basin.

The Cuyo Group succession reported here reflects the complexity in terms of depositional styles, sequence stratigraphic patterns, and controls that can be expected during the early-post rift infill of syn-rift structural depressions. Therefore, the results of this study can provide useful lessons for post-rift systems having prolific hydrocarbon production worldwide (e.g., in the Northern North Sea, Norwegian Sea, Thailand, and Argentina and Chile).
\end{abstract}

\section{INTRODUCTION}

The evolution and controls on early post-rift marine depositional systems are poorly understood, mostly because resultant deposits are typically deeply buried or heavily deformed in outcrops due to subsequent tectonic inversion (Zachariah et al. 2009a). Early post-rift infill typically tries to subdue the syn-rift remnant topography by progressive onlapping onto the margins, producing fairly subparallel stratigraphic packages in central locations and more complex patterns toward the margins (Nøttvedt et al. 1995; Watcharanantakul and Morley 2000; Zachariah et al. 2009b). Under these circumstances, sedimentation associated with these depositional systems can be influenced by regional factors such as ratio of thermal subsidence and sea-level changes (Gabrielsen et al. 2001), but also by local factors such as inherited syn-rift topography and routing of sediment supply (e.g., Zachariah et al. 2009a, 2009b; Schwarz et al. 2011), as well as localized subsidence (e.g., Færseth and Lien 2002; Cristallini et al. 2006). In turn, the complex interaction of different factors in post-rift depositional systems can also affect development and timing of regional anoxic events (Copestake et al. 2003; Zachariah et al. 2009a).

The Neuquén Basin (west-central Argentina) is a polyphase basin in which the initial configuration (Late Triassic-Early Jurassic) was characterized by fault-controlled, isolated depocenters filled mostly with volcano-sedimentary successions (Vergani et al. 1995; Franzese et al. 2006; Muravchik et al. 2011). The marine deposits of the overlying EarlyMiddle Jurassic Cuyo Group represent the early post-rift stage (Gulisano et al. 1984; Legarreta and Uliana 1996), which was characterized by a more generalized subsidence pattern, the integration of individual depressions, and a partial connection with the Proto-Pacific Ocean located toward the west (Vergani et al. 1995; Franzese and Spalletti 2001).

The sedimentary record of the early post-rift is markedly variable across the basin. In the west-central Neuquén Basin (Chacay Melehue, Fig. 1) it is represented by a general deepening-upward succession, mostly comprising fine-grained sediments deposited in a deep-marine setting (Burgess et al. 2000). Toward the east this succession also shows a 


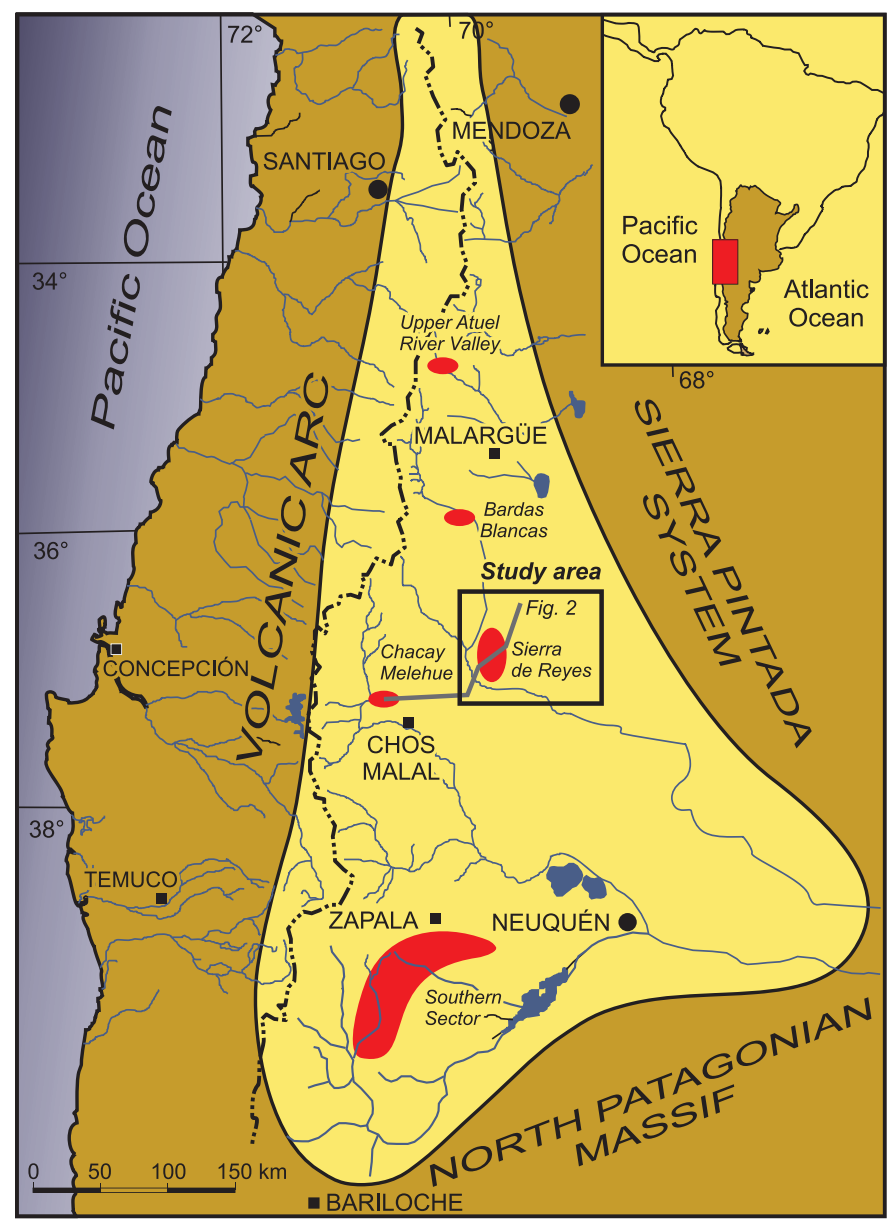

FIG. 1.-Location map of the Neuquén Basin and the study area. Additional Cuyo Group outcrops mentioned in the text are also shown (in red). The cross section shown in Figure 2 is also indicated (solid gray line)

deepening-upward trend (Gulisano 1981; Riccardi and Gulisano 1990), but is significantly coarser-grained and thinner, pinching out abruptly eastward in less than $50 \mathrm{~km}$ (Fig. 2). This information suggests that the study area acted as the margin of a marine basin flanked by terraced areas during the Early-Middle Jurassic, which likely represented the relict of footwall crests associated with an underfilled syn-rift margin system.

The aim of this paper is four-fold: 1) to document and interpret facies associations and sedimentary environments for the early post-rift Cuyo Group, combining excellent outcrops with abundant subsurface data, 2) to identify and interpret parasequences and parasequence stacking within these strata, 3) to analyze main external controls on long-term transgressive trend in the context of a Jurassic post-rift stage, and 4) to discuss the potential effect of terraced physiography on the generation of parasequence stacking patterns. This study provides a better understanding of early post-rift marine sedimentation and controls, which can provide useful lessons for other post-rift systems having prolific hydrocarbon production (e.g., northern Viking Graben in the North Sea; Pattani and Malay Basins in Thailand; Austral-Magallanes Basin in southernmost Argentina and Chile), as well as for the deep-water, continental-margin exploration.

\section{GEOLOGIC SETTING AND STUDY AREA}

The Neuquén Basin is located on the eastern side of the Andes in westcentral Argentina, between latitudes $32^{\circ}$ and $40^{\circ}$ South, covering an area of over $150,000 \mathrm{~km}^{2}$ (Fig. 1). It comprises a nearly continuous record of up to $6,000 \mathrm{~m}$ of stratigraphy from the Late Triassic to the early Cenozoic and is one of the most important petroleum provinces of the country. The sedimentary record of the Neuquén Basin includes continental and marine siliciclastics, carbonates, and evaporites, deposited under a variety of basin styles (Legarreta and Uliana 1991; Howell et al. 2005). During the Late Triassic to the earliest Early Jurassic this western border of Gondwana was characterized by large transcurrent fault systems. This led to extensional tectonics within the Neuquén Basin and the evolution of a series of narrow, relatively isolated depocenters (Franzese and Spalletti 2001), which were filled mostly with volcanic and continental successions (Franzese et al. 2006; Muravchik et al. 2011). Due to continuous subduction at the proto-Pacific margin of Gondwana, a transition from syn-rift to post-rift conditions occurred in the late Early Jurassic (Vergani et al. 1995), marked by the first marine incursion in the basin. The Neuquén Basin became a back-arc depocenter characterized by regional, slow subsidence that lasted to the end of Early Cretaceous. In the earliest stage of the post-rift phase, sediment gravity flows and mass movements were particularly common in marine settings, and this has been related to steep gradients (e.g., Legarreta and Uliana 1996; Burgess et al. 2000). In this context, low-amplitude eustatic fluctuations, as well as short-lived events of tectonic inversion, probably had a strong influence during the entire post-rift evolution (Legarreta and Uliana 1991; Howell et al. 2005), but inherited topography and mechanical subsidence had been invoked as potential local factors in the development of early post-rift strata (Legarreta and Uliana 1996; Burgess et al. 2000).

The Cuyo Group represents the early post-rift sedimentation all across the Neuquén Basin (Figs. 1, 2). It typically overlies a volcanic and volcaniclastic succession deposited during the syn-rift stage (collectively referred to as the Pre-Cuyo Cycle, Gulisano 1981; Gulisano et al. 1984), but it can also rest directly upon Paleozoic volcanic or plutonic rocks (e.g., Choiyoi Group, Fig. 2). Although the base of the Cuyo Group is marked by the occurrence of marine deposits throughout the basin, the distribution and vertical stacking patterns of these marine deposits are quite variable along strike and dip. In the southern sector of the Neuquén Basin (Fig. 1), the Cuyo Group consists of a > 600-m-thick succession with deep-marine, deltaic, and continental siliciclastic deposits, spanning from Pliensbachian to Callovian times (Gulisano et al. 1984). This succession has been extensively studied from both scientific and economic points of view (Legarreta and Uliana 1996; Cruz et al. 1999; Arregui et al. 2011). In the west-central sector of the Neuquén Basin (Chacay Melehue region, Fig. 1), basal marine deposits of the Cuyo Group are also Pliensbachian in age, but the overlying succession (up to $1 \mathrm{~km}$ thick) represents continuing deep-water sedimentation, strongly influenced by sediment gravity flows (Burgess et al. 2000). In the study area, in the eastcentral sector of the basin (Fig. 2), early post-rift accumulation started in the late Toarcian-Aalenian (Riccardi 2008; Spalletti et al. 2012), and sediments deposited mostly in shallow-marine settings.

The Cuyo Group in this central region of the Neuquén Basin has received comparatively less attention than the southern counterpart, and only recently some potential correlations between the east and west sectors have been suggested (Spalletti et al. 2012). Additionally, exploration in the Cuyo Group has received renewed attention very recently, due to its potential as an unconventional hydrocarbon resource (e.g., Legarreta and Villar 2011).

The study area is located between $36^{\circ} 40^{\prime}$ and $37^{\circ} 10^{\prime}$ South latitude (Figs. 1, 3), and covers about 3,000 $\mathrm{km}^{2}$. The area is divided by the Andean fold-and-thrust-belt front; the western sector comprises a north-southrunning anticline (Sierra de Reyes), whereas the eastern sector is relatively undeformed and the Mesozoic sedimentary succession is in the subsurface (Fig. 3). Exploration and production in this eastern region dates back to the 1970s, and more than 100 wells have been drilled in the area since. 


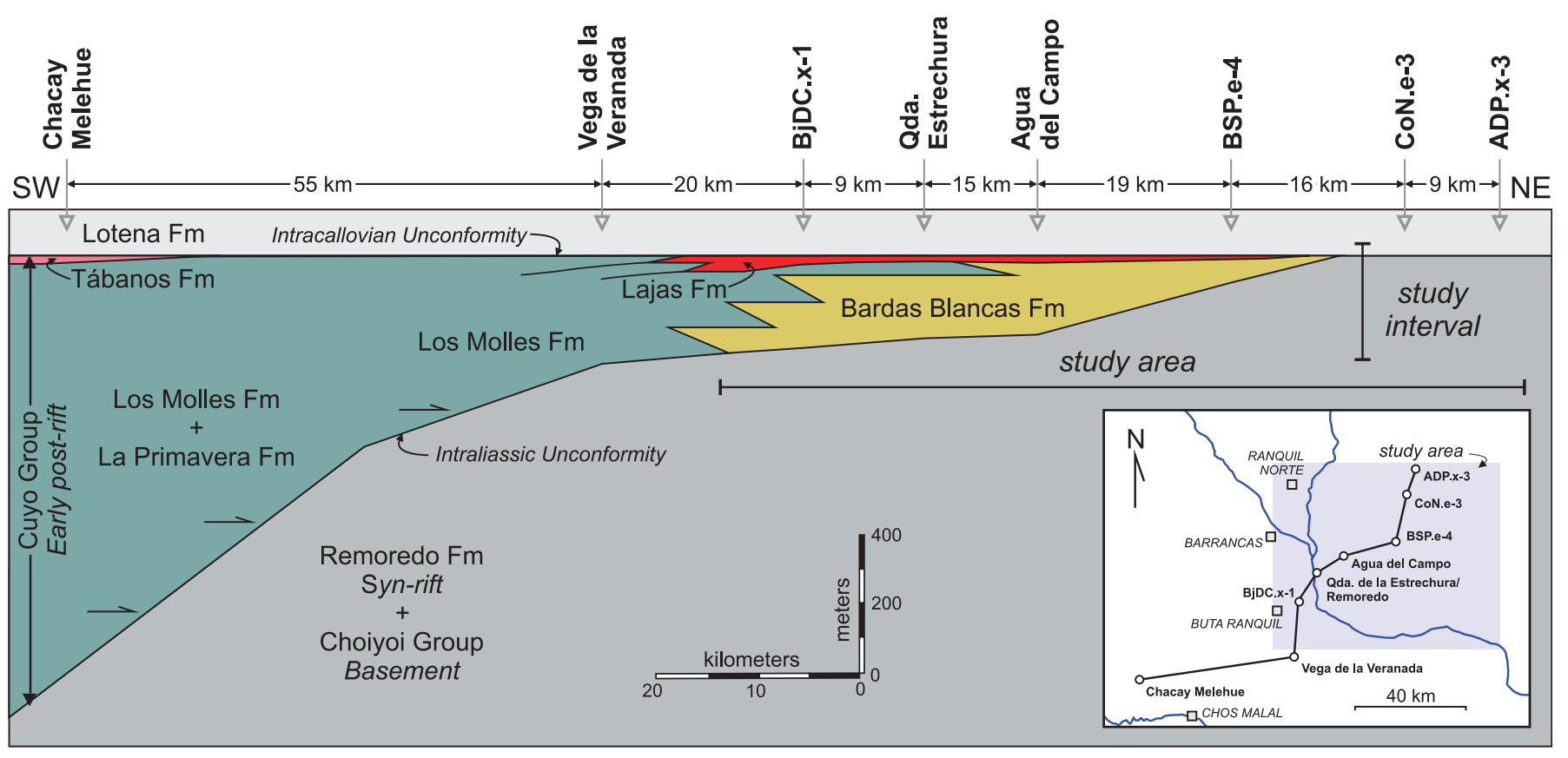

FIG. 2.-Cross section (integrating outcrop and well data) showing vertical and lateral relationships between the lithostratigraphic units representing the early post-rift Cuyo Group in central Neuquén Basin, as well as older (Choiyoi Group, Remoredo Fm) and younger (Lotena Fm) units. Modified from figure 8 of Spalletti et al. (2012) and references therein. Inset shows detailed map of the cross section.

In the study area, the Cuyo Group unconformably overlies a syn-rift unit termed the Remoredo Formation (Fig. 4), and its basal bounding discontinuity is known as the Intra-Liassic Unconformity (Gulisano et al. 1984). The Cuyo Group shows dramatic lateral changes in thickness, being up to $320 \mathrm{~m}$ thick in the southeastern sector of the study area, thinning and pinching out northeastward in less than $50 \mathrm{~km}$ (Figs. 2, 3). Internally, the unit can comprise up to three lithostratigraphic units, from base to top (Fig. 4): the Bardas Blancas Formation, the Los Molles Formation, and the Lajas Formation (Gulisano and Gutiérrez Pleimling 1994; Spalletti et al. 2012). The Bardas Blancas Formation consists of a wide range of lithologies from mudstones to pebbly sandstones; the Los Molles Formation is represented by black shales and gray mudstones, whereas the Lajas Formation is composed of amalgamated sandstones and subordinate pebbly sandstones. Macrofossils suggesting a marine affinity (ammonites, belemnites) are present throughout the succession. Biostratigraphic data based on ammonites of the study succession (Fig. 4) indicate that the Bardas Blancas Formation spans from the late Toarcian to the early Bathonian, and the Lajas Formation was deposited between the late Bathonian and the early Callovian (Riccardi 2008; Spalletti et al. 2012). The unit is unconformably bounded at its top by a basin-wide stratigraphic discontinuity (Figs. 2, 4), the Intra-Callovian Unconformity (Dellapé et al. 1978; Gulisano 1981; Gulisano et al. 1984). This unconformity represents a major regressive surface, which in some sectors of the study area places continental deposits (of the Lotena Formation) on top of the marine Cuyo strata (Veiga et al. 2011).

\section{DATA SETS AND METHODOLOGY}

This study integrates outcrop and subsurface datasets (Fig. 5). Sedimentological sections of the Cuyo Group were measured both in the eastern (Quebrada Agua del Campo locality) and the western (Quebrada de la Estrechura and Remoredo localities) flanks of the Sierra de Reyes anticline (Figs. 3, 6). Outcrop data were integrated with information from 35 boreholes drilled in the eastern sector of the study area and provided by formerly Repsol-YPF S.A. (now YPF S.A.). About $100 \mathrm{~m}$ of core from seven wells were described in detail (Fig. 5). Cutting descriptions and well- log suites (mostly gamma-ray, spontaneous potential, density, and sonic logs) from the 35 boreholes were also used to interpret the lithology, and subsequently integrated and calibrated with core description.

Sedimentary sections both in the exposed localities (decimeter-scale detail) and the core (centimeter-scale detail) were measured describing facies attributes (e.g., texture, physical sedimentary structures, etc.), marine invertebrate fauna, and trace fossils (Fig. 6). Photomosaic analyses and paleocurrent measurements were also carried out in the field.

\section{FACIES ASSOCIATIONS}

Sedimentary facies analysis of the outcrop sections and cores of the Cuyo Group allowed the identification and interpretation of lithofacies, ranging from pebbly conglomerates to mudstones. These sediments are mainly siliciclastic, but gravel- and sand-size carbonate bioclasts can be present in variable proportion. Sedimentary facies were subsequently regrouped in six facies associations, interpreted to represent a wide range of marine depositional conditions, from upper-shoreface to lower-offshore settings.

\section{Upper-Shoreface Facies Association}

Description.-This facies association comprises mostly normally graded beds $(0.3-1.5 \mathrm{~m}$ thick) from pebbly sandstones to coarse- or medium-grained sandstones (Figs. 6, 7A). Thin layers of conglomerates $(<20 \mathrm{~cm}$ thick) with pebbles up to $20 \mathrm{~mm}$ long and a chaotic fabric are also present. Sand-size bioclasts are common, typically showing a high degree of fragmentation. They are derived mostly from bivalves, but ammonite and belemnite fragments are also present. Sandstones have plane bed, or less commonly show trough cross-stratification (sets $<0.3 \mathrm{~m}$ thick), preferentially oriented to the west and southwest. Bioturbation ranges from uncommon to moderate and is dominated by Palaeophycus, Ophiomorpha (Fig. 7B), and Arenicolites.-Tree trunks and plant remains are occasionally preserved in bedding planes. This facies association was recorded solely at the base of the Cuyo Group in the outcrop sections, and was inferred from well cuttings toward the east. 


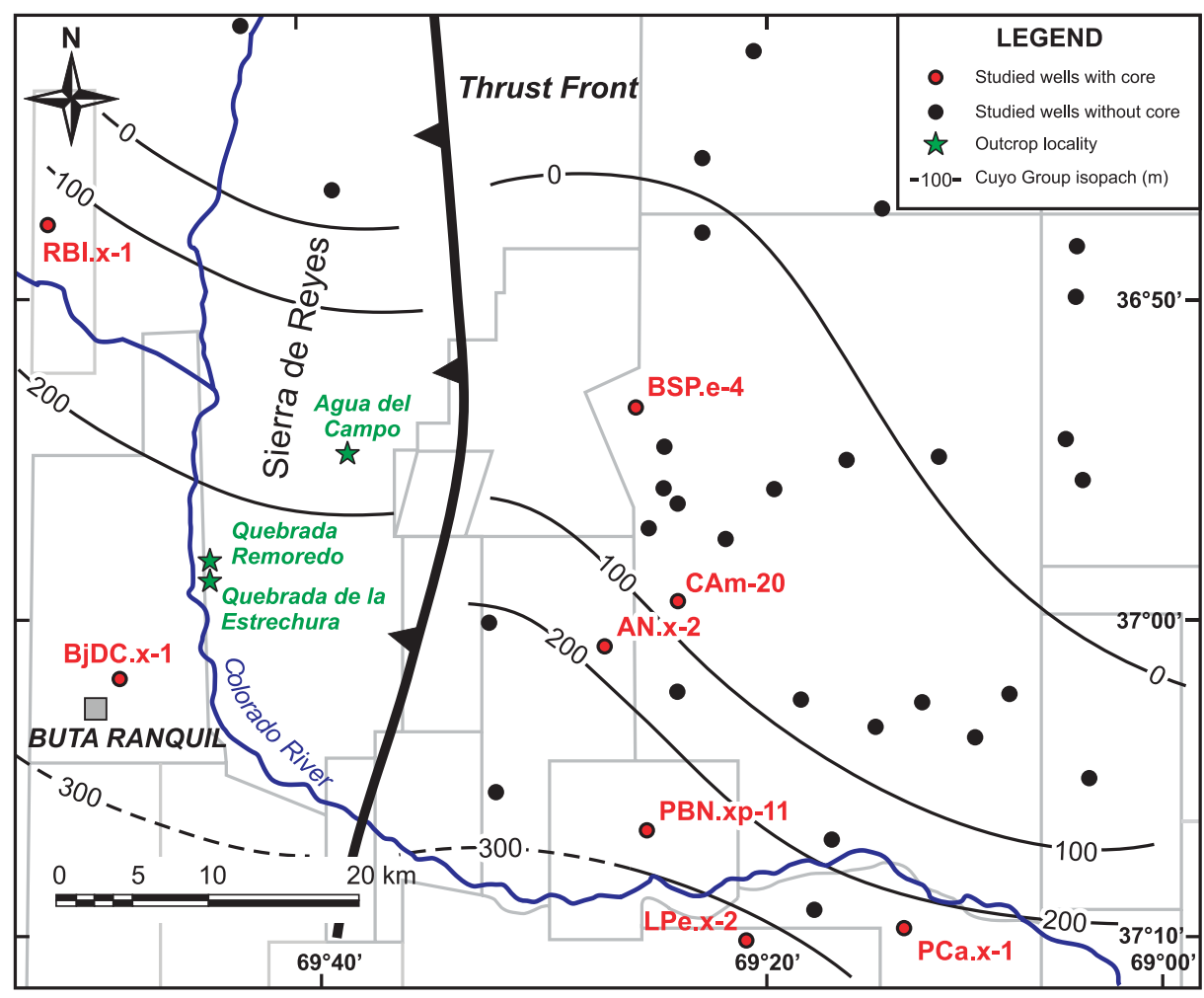

FIG. 3.- Map of the study area showing the location of sections measured in the Cuyo Group and wells available for this study. Gray solid lines show the boundaries between oil fields. Reconstructed isopachs for the study unit are also presented.
Interpretation.-Coarse-grained textures, high proportion of marine skeletal remains, and the trace-fossil suite, interpreted to represent the Skolithos ichnofacies, suggest that this facies association was deposited in a high-energy nearshore setting (cf. Pemberton et al. 1992; Clifton 2006). Plant remains point to a terrestrial input whereas massive conglomerates suggest the occurrence of river-related hyperpycnal flows (Mulder et al. 2003). However, final deposits within this setting were most probably the result of nonchannelized, unidirectional currents, which redistributed both extrabasinal siliciclastics and intrabasinal bioclasts, under either upper-flow-regime or lower-flow-regime conditions. This facies association is interpreted to be an upper-shoreface environment, influenced by terrestrial supply (Clifton 2003; Varban and Plint 2008) and significant reworking by longshore currents (Clifton 1973; Hart and Plint 1995).

\section{Lower-Shoreface Facies Association}

Description.-This facies association is composed of amalgamated, medium- to thick-bedded ( $0.15-0.80 \mathrm{~m}$ thick), very fine- and fine-grained

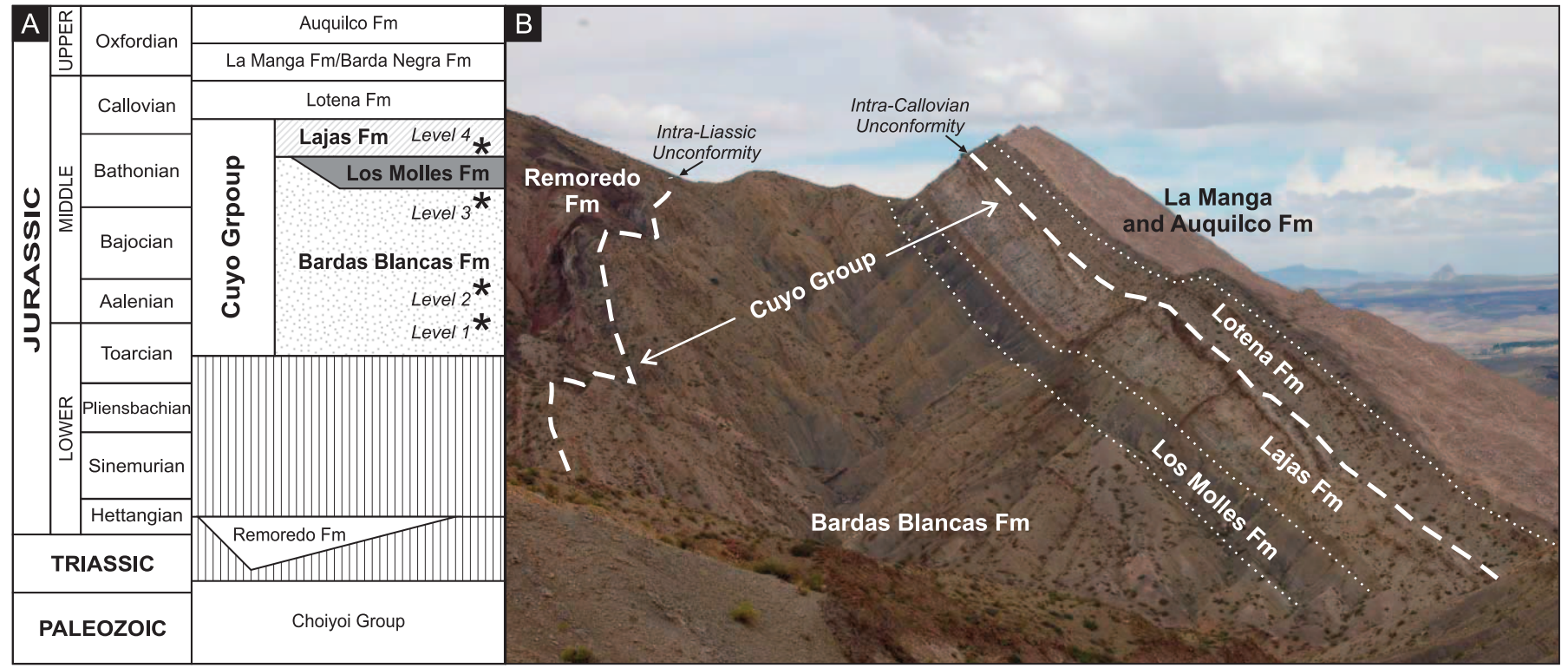

FIG. 4.-A) Chronostratigraphic chart for the study area, showing the temporal distribution of the Cuyo Group succession. Asterisks (Levels 1 to 4 ) show the location of ammonite levels described by Spalletti et al. (2012). B) General view of the Cuyo Group deposits at Quebrada de la Estrechura in the southwestern sector of the Sierra de Reyes showing the boundaries between the lithostratigraphic units identified in this study. 


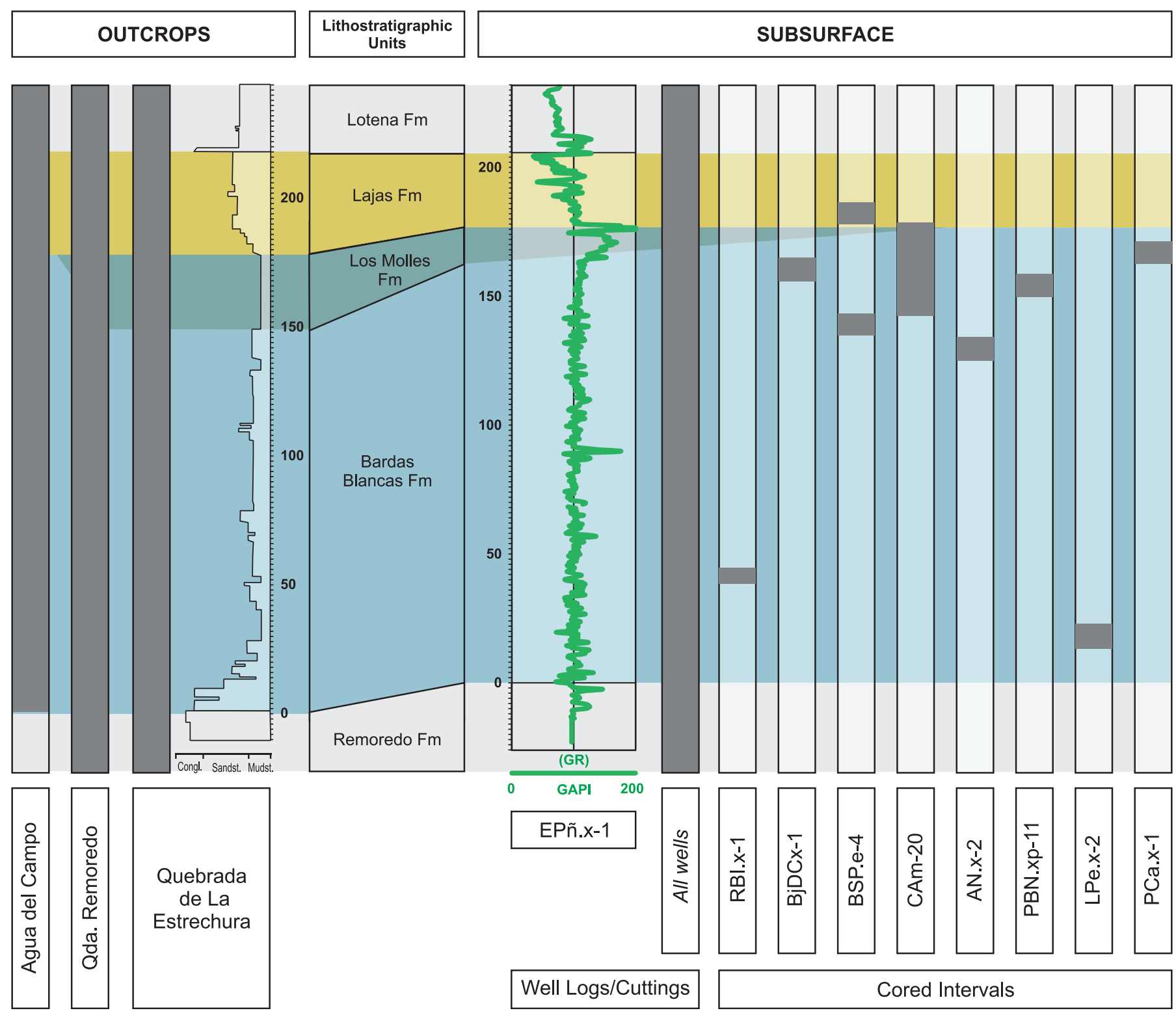

FIG. 5.-The Cuyo Group was investigated by a combination of outcrop and subsurface data sets. Three outcrop sections plus well logs and cuttings from 35 boreholes cover the entire Cuyo Group, as well as underlying and overlying units. About $100 \mathrm{~m}$ of cores were additionally described. They are preferentially distributed in the upper half of the unit, but some cored intervals are also located near its base.

sandstones having two different suites of physical structures. Some sandstone packages are dominated by hummocky cross-stratification (Fig. 7B) with subordinate swaly cross-stratification and plane bed (e.g., Fig. 6, Agua del Campo Section, between 98 and 103 m). Lenses of shell concentrations with preferentially oriented bioclasts are common at the bases of these beds, whereas tops with symmetrical ripples are uncommon. Parting lineation and plant remains are common. Sandstone packages can be alternatively characterized by fine- to medium-grained sandstones with current-ripple cross-lamination and asymmetric rippled tops (e.g., Fig. 6, Quebrada de la Estrechura Section, between 187 and $189 \mathrm{~m}$ ). Trace fossils include Arenicolites (Fig. 7D), Skolithos, Palaeophycus, and Ophiomorpha, but bioturbation varies from uncommon in HCS facies to abundant in ripple cross-laminated facies, completely disrupting the original lamination in some cases. This facies association is common in the eastern sector of the Sierra de Reyes anticlinal and was also recognized in cores (namely CAm-20 and PCa.X-1).

Interpretation.-HCS beds are associated with purely oscillatory and/or combined flow developed during storms (Harms et al. 1975; Dott and Bourgeois 1982). Erosional stages of these flows likely incorporated benthic macrofauna from shallower marine zones and transported it farther downdip, producing allochthonous shell beds. The amalgamation of these event beds also suggests significant erosion of fairweather sediments indicating, in turn, a lower-shoreface setting for these deposits (Walker and Plint 1992). Sandstones with ripple cross-lamination are also interpreted to represent lower-shoreface conditions, but with a relatively low proportion (or preservation) of storm deposits. The trace-fossil suite in this facies association is thought to represent a Skolithos ichnofacies developed under moderate hydrodynamic energy in a marine environment (cf. Pemberton et 
al. 1992), and the variable intensity of bioturbation is likely related to changes in sedimentation rates (MacEachern and Pemberton 1992).

\section{Offshore-Transition Facies Association}

Description.-This facies association consists mostly of very finegrained sandstones and muddy sandstones, with a subordinate proportion of sandy mudstones (Fig. 6). These deposits are typically massive due to very intense bioturbation (Fig. 8A), but occasionally faint ripple crosslamination is recognized. Beds are tabular and range mostly from 0.10 to $0.40 \mathrm{~m}$ in thickness, but a few beds can be up to $1.50 \mathrm{~m}$ thick. Macrofossils are very common, with bioclasts from endobenthic and semi-endobenthic bivalves being the most abundant. Belemnite and ammonite fragments are also present. Bioclasts present a low to moderate degree of fragmentation, and articulated specimens are common, occasionally preserved in life position (Fig. 8B). The trace-fossil suite includes, in order of abundance, Teichichnus, Asterosoma, Rosselia, Chondrites, Planolites, Thalassinoides, Rhizocorallium, Palaeophycus, Phycosiphon, and Zoophycos. Bioturbation intensity varies from very high to moderate (Fig. 8C). This facies association also includes normally graded, sandstone beds ( 0.2 to $1.0 \mathrm{~m}$ thick), which can be traced for hundreds of meters. They can be massive and/or have plane bed, and occasionally shells are concentrated at their bases (Fig. 8D). In these sandstone beds bioturbation is typically low and decreases downwards from their tops. Ophiomorpha and Skolithos are dominant, but Phycosiphon is also common, frequently leaving lam-scram textures (cf. Pemberton et al. 1992). This facies association is broadly distributed in outcrop and core studied sections (Figs. 5, 6).

Interpretation.-The trace-fossil suite present in the muddy sediments of this facies association shows a relative high diversity and is clearly dominated by traces related to deposit feeders, with subordinate forms associated with filter organisms (e.g., Rosselia). The trace-fossil suite is interpreted to represent an archetypal Cruziana ichnofacies, likely developed in a marine setting located below fairweather wave base but well above storm wave base (MacEachern et al. 2007), therefore an offshore-transition zone (Reading and Collinson 1996). Moreover, high diversity and intensity of bioturbation probably suggest moderate energy conditions, normal marine salinity, and low sedimentation rates (Morris et al. 2006; MacEachern and Bann 2008), which are optimal conditions for colonization by endobenthic fauna. In this scenario, the preservation of only a few sandstone beds is probably related to intense reworking by bioturbation, which homogenized fairweather muds and sandy storm beds (producing large volumes of sandy mudstones). The few preserved event beds could have been emplaced by ebb storm-related flows, lowconcentration turbidity currents triggered during exceptionally large storms, or even river-induced hyperpycnal flows (e.g., Walker and Plint 1992; Mulder et al. 2003).

\section{Upper-Offshore Facies Association}

Description.-This facies association is composed largely of sandy mudstones and silty mudstones (Figs. 6, 9A), with a low proportion of mudstones and muddy sandstones. As grain-size changes are small, bedding contacts are diffuse, but always roughly parallel, defining tabular beds (Fig. 9B), which typically range from 0.20 to $0.80 \mathrm{~m}$ in thickness. The trace-fossil association is represented by Zoophycos (Fig. 9A), Chondrites, Phycosiphon, Planolites, Teichichnus, Helminthopsis, Thalassinoides, Rhizocorallium, and small ?Skolithos. Bioturbation intensity ranges from high to very high. Fragments of ammonites and belemnites are frequent, but benthic macrofossils are uncommon (mostly oysters). Discrete sandstone beds are less common than in the previous facies association, and they show plane bed and bioturbation decreasing from top to bottom (Fig. 9C). This facies association is very well represented in the western sector of the study area (outcrops) and has been also recorded in several cores (Figs. 6, 9).

Interpretation.-The trace-fossil suite recorded in the sandy and silty mudstones (dominated by Zoophycos, Phycosiphon, and Helminthopsis) is attributed to a distal Cruziana ichnofacies, indicating low-energy conditions and cohesive substrates (MacEachern et al. 2007), as well as pore waters with persistent oxic conditions (Martin 2004). This, together with the finer sediments and relatively lower proportion of sandy event beds than this facies association shows compared to the previous one, suggests a relatively distal depositional setting. This facies association is interpreted to represent an upper-offshore condition, around the storm wave base.

\section{Lower-Offshore Facies Association}

Description.-This facies association comprises several-meter-thick packages of gray mudstones and/or black shales and is relatively uncommon in the outcrop sections, occurring either near the base or the top of the Cuyo Group (Fig. 6). It has also been recorded in a cored well (BjDC.x-1, Fig. 5). Gray mudstones range from massive to crudely laminated (Fig. 9D), with a trace-fossil suite composed of Zoophycos, Phycosiphon, Chondrites, and ?Scolicia. Foraminifers are also common in this facies. In turn, black shales (Fig. 9E) are typically platy (partingassociated fissility $>1 \mathrm{~mm}$, cf. Stow 2007) and characterized by the virtual absence of trace fossils and scarce fragments of small, thin-shelled bivalves. Additionally, centimeter-thick tuffaceous layers occur within black shales.

Interpretation.-All mudstones in this facies association are interpreted to be the result of settling from suspension in very low-energy hydrodynamic conditions and devoid of bottom currents. Additionally, the recorded trace-fossil suite is interpreted to represent a Zoophycos Ichnofacies (cf. MacEachern et al. 2007). Collectively, this points to a marine setting below storm wave base, likely a lower-offshore to outershelf environment (MacEachern et al. 2005). In this distal setting, thick fine-grained intervals with a high proportion of organic content, preserved lamination, and thin-shell pleurotectic bivalves (sensu Schatz 2005), probably formed under protracted dysoxic to anoxic conditions, in a saturated water-sediment interface and with soupy substrates (Doyle et al. 2005). These conditions could have been coupled with high rates of organic-matter rain (Meyers 2006). On the other hand, mudstones showing alternation of laminated and burrowed intervals could represent episodic fluctuations of oxygen levels from dysoxic to oxic, respectively (Frey and Pemberton 1984; Bromley 1996; Martin 2004).

\section{Delta-Front Facies Association}

Description.-This facies association is composed of fine- to coarsegrained sandstones and pebbly sandstones. Sandstone beds are mostly massive, tabular, and ranging from 0.50 to $2.10 \mathrm{~m}$ in thickness (Fig. 10A). Less commonly, however, sandstone beds are thinner (0.15-0.40 m thick) and they show planar or trough cross-bedding (Fig. 10B), occasionally grading to cross-lamination at the bed tops. These later beds show paleocurrents running mostly to southwest and south. In turn, pebbly sandstones are always massive and matrix supported, with up to $10 \mathrm{~mm}$ prolate, extraformational pebbles evenly distributed throughout the beds. Additionally, mudstone rip-up clasts (up to $100 \mathrm{~mm}$ ) are frequent in this facies association, either chaotically distributed in sandstone beds or forming better-organized intraformational conglomerates. This facies 


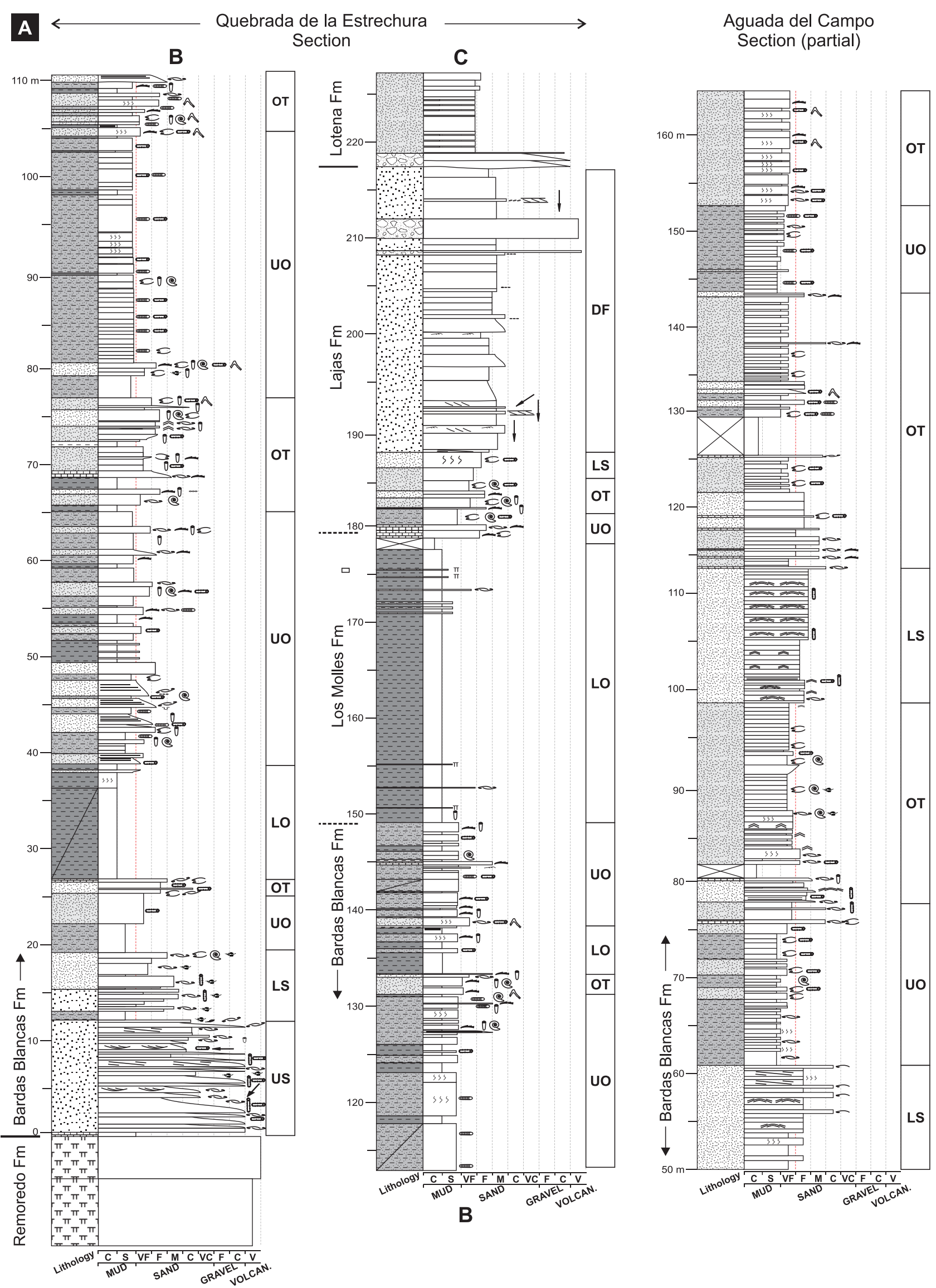


B

Lithology

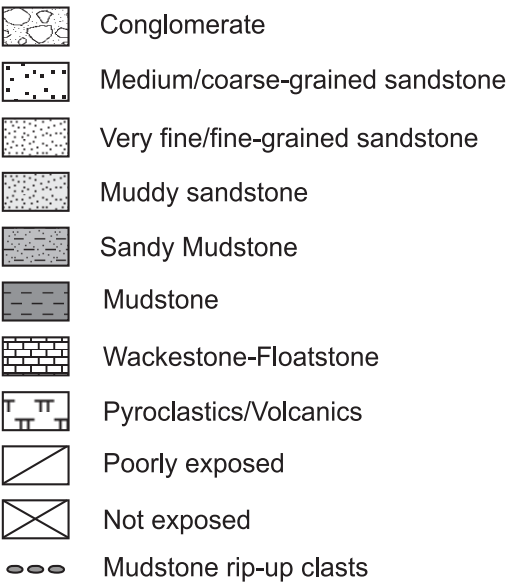

\author{
Sedimentary structures \\ Massive \\ Current ripples \\ Wave ripples \\ Plane bed \\ Hummocky cross-stratification \\ Low-angle cross-stratification \\ Planar cross-stratification \\ Trough cross-stratification

\section{Paleoflow indicators \\ Cross-stratification}

FIG. 6.-Continued.

\author{
Fossils and Bioturbation \\ G Vertical burrows \\ $\hookrightarrow$ Horizontal burrows \\ Zoophycos \\ ^ Thalassinoides \\ S) Intense Bioturbation \\ $\approx \approx$ Bivalves (undifferenciated) \\ Oysters \\ (9) Ammonites \\ 0 Belemnites \\ - Tree trunks and plant remains
}

association was recorded solely at the top of the Cuyo Group in the western outcrops (Fig. 6). It consists of a 30-m-thick sandstone wedge with depositional clinoform shapes up to $10 \mathrm{~m}$ high and dipping $\left(10-20^{\circ}\right)$ toward the northwest (Fig. 10C). This wedge abruptly pinches out across a 2-km-long, S-N-oriented outcrop, but time-equivalent finer-grained deposits are present in the southwestern sector of the study area (well BJC.x-1, Fig. 2).

Interpretation.-Deposits belonging to this facies association suggest a significant supply of coarse-grained sediments by unidirectional currents. The development of steep depositional clinoforms is rather common in river-dominated transitional systems (e.g., Howell et al. 2008), typically characterizing fluvial delta-front settings (van den Bergh and Garrison 2004; Fielding 2010; Hampson et al. 2011). Additionally, the absence of trace fossils might reflect stressed conditions, which could be the result of mixing of marine and fresh waters, episodic sedimentation, and/or a high proportion of suspended material in the water column (MacEachern et al. 2005; MacEachern and Bann 2008). In this context, massive sandstones and pebbly sandstones could have been the product of highly concentrated currents flowing toward the toe of the delta front (Bhattacharya and Walker 1982; Howell et al. 2008; Hampson et al. 2011), and rapidly depositing their finer-grained (sandy) load out from suspension (Arnott and Hand 1989). In turn, cross-bedded sandstones, which suggest the development of subaqueous dunes migrating oblique or perpendicular to clinoform slopes, could reflect reworking associated with longshore currents (Plint et al. 2009; Fielding 2010).

\section{DEPOSITIONAL SYSTEMS}

Vertical and lateral relationships of facies associations in the study area allowed the identification of two contrasting depositional systems for the
Cuyo Group sequence. The first depositional system represents a stormand wave-dominated marine environment, and was established from the onset of sedimentation in the studied area. The sedimentary record of this older depositional system is widely distributed both in space and time, spanning the late Toarcian to the early Bathonian (including the Bardas Blancas, the Los Molles, and the lower Lajas formations). Eventually, this long-lived system was replaced toward the top of the Cuyo Group by a fluvio-deltaic depositional system (represented by the upper section of the Lajas Formation). In contrast to the previous case, deposits associated with this system are both spatially and temporally restricted (late Bathonian-early Callovian).

\section{Toarcian-Bathonian Depositional System}

This storm- and wave-dominated open-marine depositional system encompasses a wide range of environments, ranging from upper shoreface to lower offshore. The shoreface setting was influenced by wave processes, but also by fluvial input. Sand- and gravel-size material was likely introduced in the upper shoreface by diluted and hyperpycnal flows and subsequently redistributed by longshore currents. In this nearshore setting, fluctuations in salinity and/or turbidity were never so dominant that colonization of sandy substrates by benthic fauna was inhibited. In turn, accumulation of sands in the lower shoreface was mostly the result of combined and purely oscillatory flows (HCS and SCS beds), probably associated with storm events. However, sheltered areas or periods with less intense (or less frequent) storm events probably favored the accumulation under fairweather waves (cross-laminated facies). These relatively more stable sandy substrates underwent extensive bioturbation.

Offshore-transition and upper-offshore subenvironments, in the marine profile between fairweather wave base and storm wave base, represented a spectrum of processes and resulting sediments. The decreasing proportion

\section{$\leftarrow$}

FIG. 6.-A) Selected outcrop sections of the Cuyo Group, showing facies and lithostratigraphy, as well as the depositional environments interpreted from the facies association analysis presented in this study. Logs are located in Figure 3. US, Upper Shoreface; LS, Lower Shoreface; OT, Offshore Transition; UO, Upper Offshore; LO, Lower Offshore. B) Legend for outcrop sections in Figure 6A. 

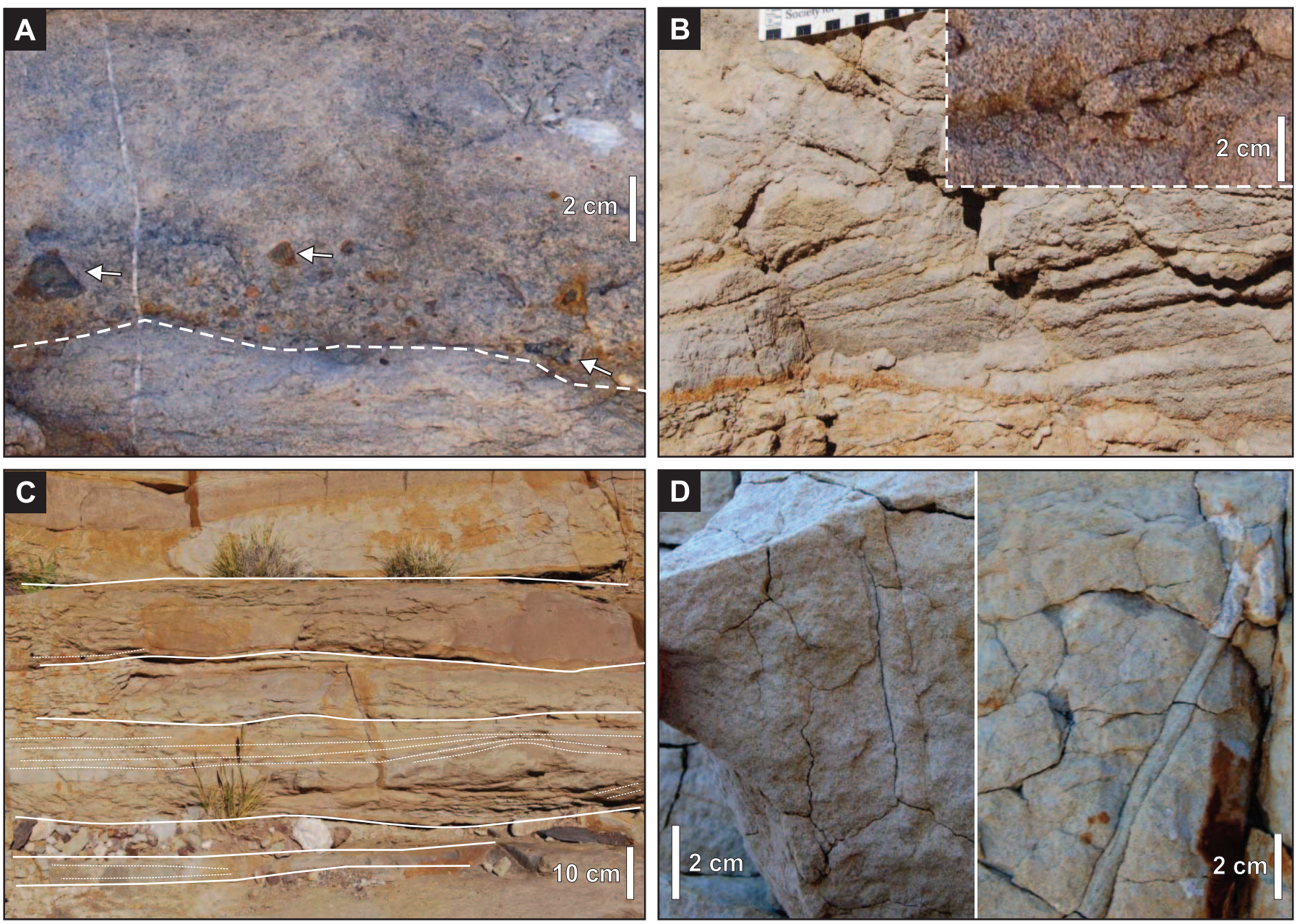

FIG. 7.-Main attributes of upper-shoreface facies association (A, B) and lower-shoreface facies association (C, D). A) Pebbly sandstone grading upward to coarsegrained sandstone. Pebbles are floating in a sandy matrix and are poorly organized. B) Coarse-grained sandstone with (trough?) cross-stratification. White and black bars are $1 \mathrm{~cm}$ long. Ophiomorpha (inset) is common in these coarse sediments. C) Amalgamation of fine-grained sandstones having hummocky cross-stratification and/or plane bed, typical of facies association 2. D) Trace fossils in this facies association are typically characterized by vertical burrows such as Arenicolites (left) and ?Skolithos (right).

of sand-size material in these deposits (from muddy sandstones to sandy mudstones) suggests a decreasing recurrence of sandy event beds down the system, but a similar capacity of deposit-feeder organisms to rework the sands during inter-event periods. In other words, during reduced sand supply the infaunal reworking equaled or exceeded the sedimentation rates (Morris et al. 2006; MacEachern and Bann 2008). Under these conditions, only the thickest (and less frequent?) event beds were preserved in the stratigraphic record. As for endobenthic and semiendobenthic bivalves, their development was apparently controlled by substrate types, mostly colonizing the coarser substrates developed in the offshore-transition zone.

Finally, in the deepest regions of this depositional system (i.e., lower offshore) muds were deposited from suspension almost constantly. Bottom conditions were characterized either by long-lived dysoxic to anoxic conditions, or by cyclic fluctuations between dysoxic and oxic conditions. Depleted levels of oxygen in the substrate are typically related to stagnant, stratified waters and local sediment starvation (e.g., Schulte et al. 2011), while dysoxic conditions were likely related to the frequency of flows affecting this deepest part of the depositional system.

Correlations between outcrop sections allowed the identification of a clear proximal-to-distal trend within the Toarcian-Bathonian depositional system (Fig. 11). In the northeastern sector, about two-thirds of its record is represented by shoreface and offshore-transition deposits, whereas in southwestern localities those deposits represent less than onefourth of the stratigraphic section. This polarity of the marine system, with proximal sectors to the NE and deeper conditions toward the SW, is further supported by subsurface data. For example, logs and cores of wells BjDC.x-1 and LPe.x-2 suggest relatively fine-grained sediments, mostly interpreted as offshore to offshore-transition deposits (Fig. 12). Time-equivalent fluvial deposits of the studied Toarcian-Bathonian depositional system, if they ever accumulated, were not preserved, at least in the study area.

\section{Late Bathonian-Early Callovian Depositional System}

The topmost succession of the Cuyo Group represents the abrupt arrival of a river-dominated deltaic system into the study area across a basal, erosional surface (Fig. 12). The delta-front setting was reconstructed from the western outcrop sections (Fig. 11). In that sector of the deltaic system, river-related, high-concentration currents were common, producing deposition of thick gravel- and/or sand-dominated beds. Those currents also affected normal marine waters (e.g., increasing turbidity and/or decreasing salinity), which in turn discouraged benthic colonization. Occasionally, longshore currents produced sand reworking, likely in the upper part of the delta-front setting. 

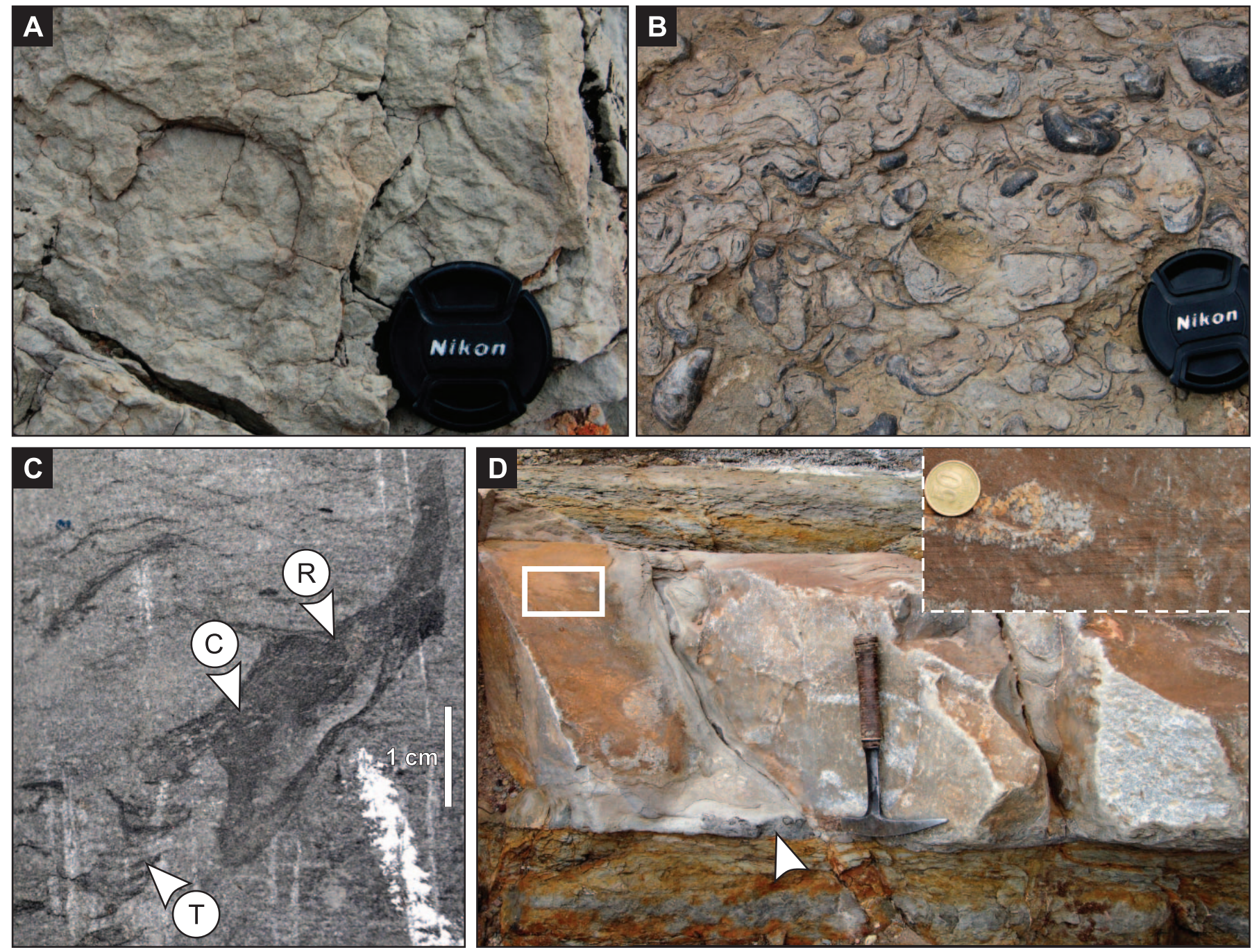

FIG. 8.-Main attributes of the offshore-transition facies association. A) Plan view of muddy sandstone showing intense bioturbation and well preserved Thalassinoides. Lens cap for scale (5 cm long). B) Cross-section view of bioclastic muddy sandstone composed almost entirely of oysters. Note high density and relatively low fragmentation of specimens, suggesting autochthonous to parautochthonous fossil concentrations. Lens cap for scale (5 $\mathrm{cm}$ long). C) Some of the ichnogenera typically present in FA3, as seen in core (well NAN.x-2). C, Chondrites; R, Rosselia; T, Teichichnus. D) Normally graded sandstone, with bioclasts at its base (arrow) and massive fine-grained sandstone in its lower half (hammer for scale is $33 \mathrm{~cm}$ long). Inset shows that the upper part of the bed is dominated by plane bed (coin for scale is $2 \mathrm{~cm}$ wide)

Delta-top deposits of this depositional system are not preserved, and if they were ever deposited, were probably removed by extensive erosion associated with the overlying unconformity (Fig. 11). On the other hand, relatively distal deposits of this river-dominated deltaic system are inferred from wells located toward the southwest of the exposed section (BjDC.x-1, Fig. 12). Moreover, farther to the west, time-equivalent deposits are dominated by fine-grained deposits (see Vega de la Veranada, Fig. 2). Thus, although the system could have prograded locally to the northwest (as suggested by exposed clinoforms, Fig. 10C), it seems reasonable to assume that this system was broadly deepening toward the west-southwest, i.e., in the same direction as the older marine system.

\section{SEQUENCE ARCHITECTURE OF THE POST-RIFT SUCCESSION}

\section{High-Frequency Cycles: Parasequences}

The stratigraphic succession corresponding to the Toarcian-Bathonian Depositional System can be subdivided into several coarsening-upward high-frequency cycles (Fig. 11). These cycles, varying from 7 to $50 \mathrm{~m}$ in thickness, most commonly comprise gradual vertical transitions to adjacent shallower facies associations recognized in this study (Figs. 11, 13A). The packages and their bounding surfaces can be correlated between outcrop sections and, with less confidence, into the subsurface (Fig. 12), and all of them show an increase in the proportion of finergrained (deeper) sediments toward the southwest.

These high-frequency cycles are bounded at their tops by sharp surfaces indicating abrupt deepening of the depositional system and landward displacement of facies belts, thus corresponding to flooding surfaces (cf. Van Wagoner et al. 1988, 1990). These surfaces do not show, for the most part, evidence of physical erosion of the underlying sediments. This is expected considering that most of the recognized discontinuities are developed onto sediments deposited below fairweather wave base. However, bounding surfaces topping shoreface deposits are occasionally associated with thin concentrations of skeletal remains and pebbles. These relatively coarse layers are interpreted to represent transgressive 

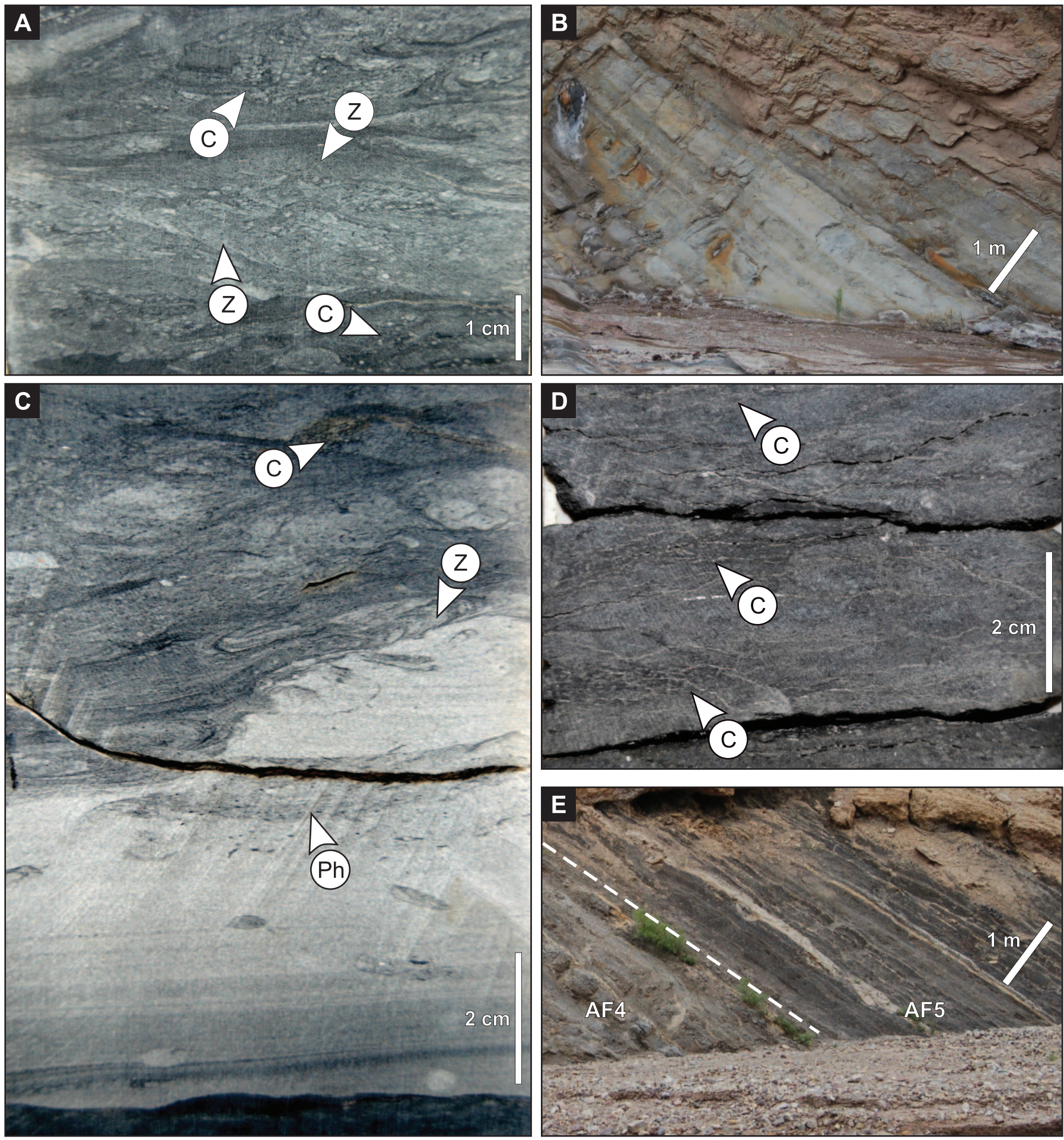

FIG. 9.-Main attributes of upper-offshore facies association (A-C) and lower-offshore facies association (D, E). A) Core view of an intensely bioturbated sandy mudstone, facies that dominates in this facies association. C, Chondrites; Z, Zoophycos (well BSP.e-4). B) Outcrop view showing tabular geometry and diffuse bedding contacts of these sandy mudstones. C) Core view of an event sandstone bed in a muddy-sandstone background (well BSP.e-4). Note sharp base and well developed plane bed in the event bed, as well as bioturbation that decreases downwards. Ph, Phycosiphon. D) Core view of gray mudstones showing bioturbation by Chondrites. These deposits characterize lower-offshore conditions. E) Black shales as seen in outcrop (Quebrada de la Estrechura section). Note fissility and darker color than previously described deposits (white layers are tuffaceous beds). 

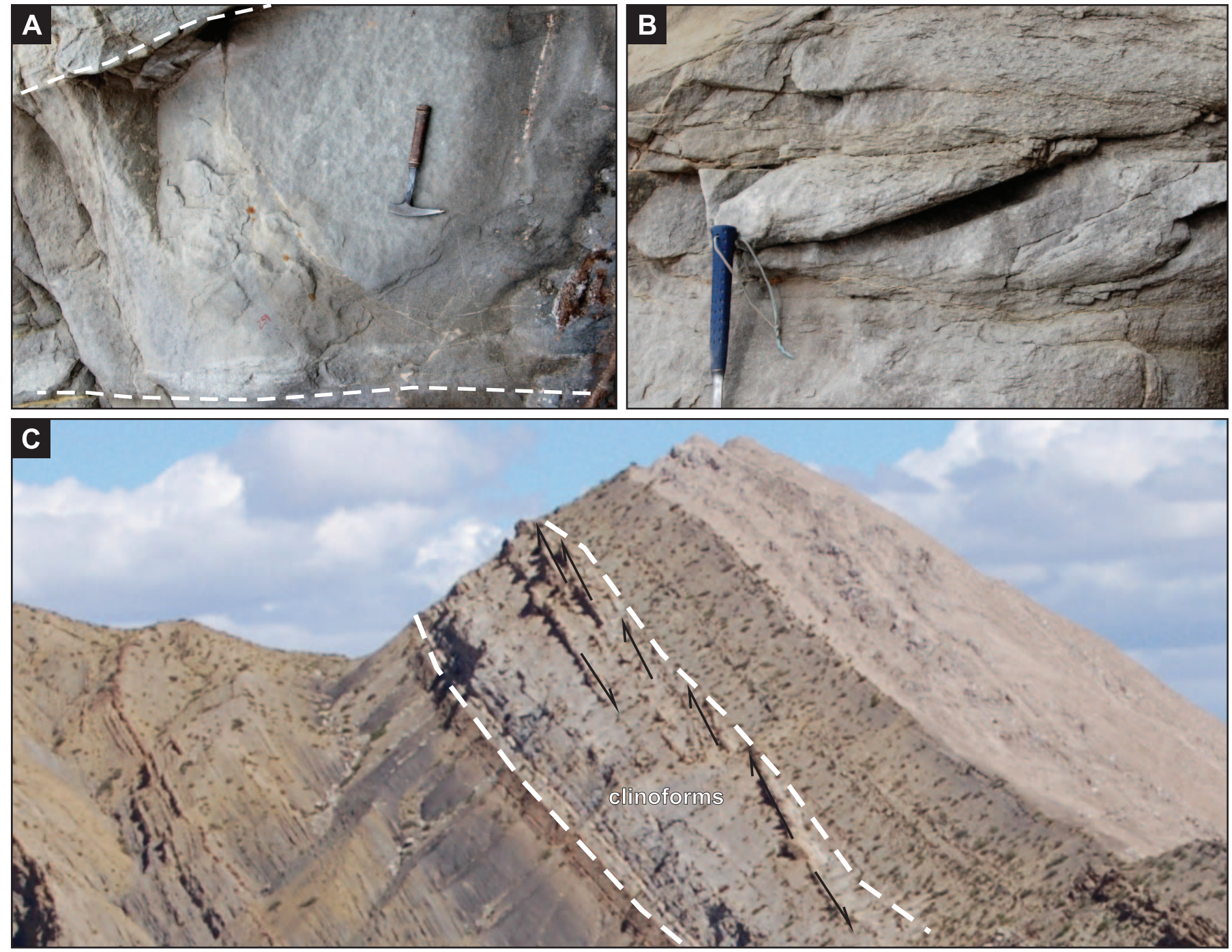

FIG. 10.-Main attributes of delta-front facies association. A) Detail of massive, thick-bedded sandstone, typical of this facies association. B) Detail of cross-bedded, medium-grained sandstone. Paleoflow to southwest. Hammer for scale in Parts A and B (33 cm long). C) Panoramic view of facies association 6 showing large-scale inclined surfaces downlaping onto a horizontal surface. They are interpreted to represent deltaic depositional surfaces (clinoforms).

lags, and they point to partial erosion and winnowing of pre-existing sediments during shoreline retreat (e.g., Swift 1968; Cattaneo and Steel 2003). When present, the transgressive lag is always less than $20 \mathrm{~cm}$ thick, therefore representing a negligible thickness of the individual cycles.

Considering that most of the high-frequency cycles recognized in the Cuyo succession record regressive events bounded by non-erosional flooding surfaces, they thoroughly conform to the original definition of parasequence (sensu Van Wagoner et al. 1998, 1990), which is one of the different types of high-frequency cycles that can develop in shallow-marine settings (e.g., Zecchin and Catuneanu 2013). In this sense, nine parasequences have been defined in the distal part of the study area, whereas only the youngest four are recorded in the marginal sector (Fig. 12).

Smaller-scale coarsening-upward cycles ( $<3 \mathrm{~m}$ thick) are occasionally preserved within the Cuyo parasequences. These are particularly well developed within upper-offshore and offshore-transition deposits (Fig. 13B) and are bounded by surfaces that represent minor changes in grain size (e.g., from sandy mudstones to silty sandstones). These packages are interpreted to represent bedsets (sensu Van Wagoner et al. 1990), reflecting minor, if any, shifts of the facies belts (Hampson et al.
2011). Alternatively, these could be packages generated by autocyclic processes, for example associated with fluctuations in the intensity of storm waves responsible for bringing sand to the distal segment of the depositional system (Storms and Hampson 2005).

\section{Parasequence Sets and Shoreline Trajectory}

The vertical stacking patterns of parasequences, termed parasequence sets, reflect long-term ratios between relative sea-level change and sediment supply (Van Wagoner et al. 1990). According to the landward or seaward displacement of facies belts, parasequence sets can be retrogradational or progradational, respectively, or aggradational if the system remains stationary through time (Van Wagoner et al. 1990). The vertical stacking of parasequences within the Cuyo succession allowed the definition of four different parasequence sets (named I to IV from base to top), which show a range from highly retrogradational to progradational patterns (Figs. 11, 12).

Parasequence Set I comprises the oldest three parasequences recorded in the study area (Figs. 11, 12). The individual cycles are less than $10 \mathrm{~m}$ thick (truncated at their tops), and collectively this parasequence set 


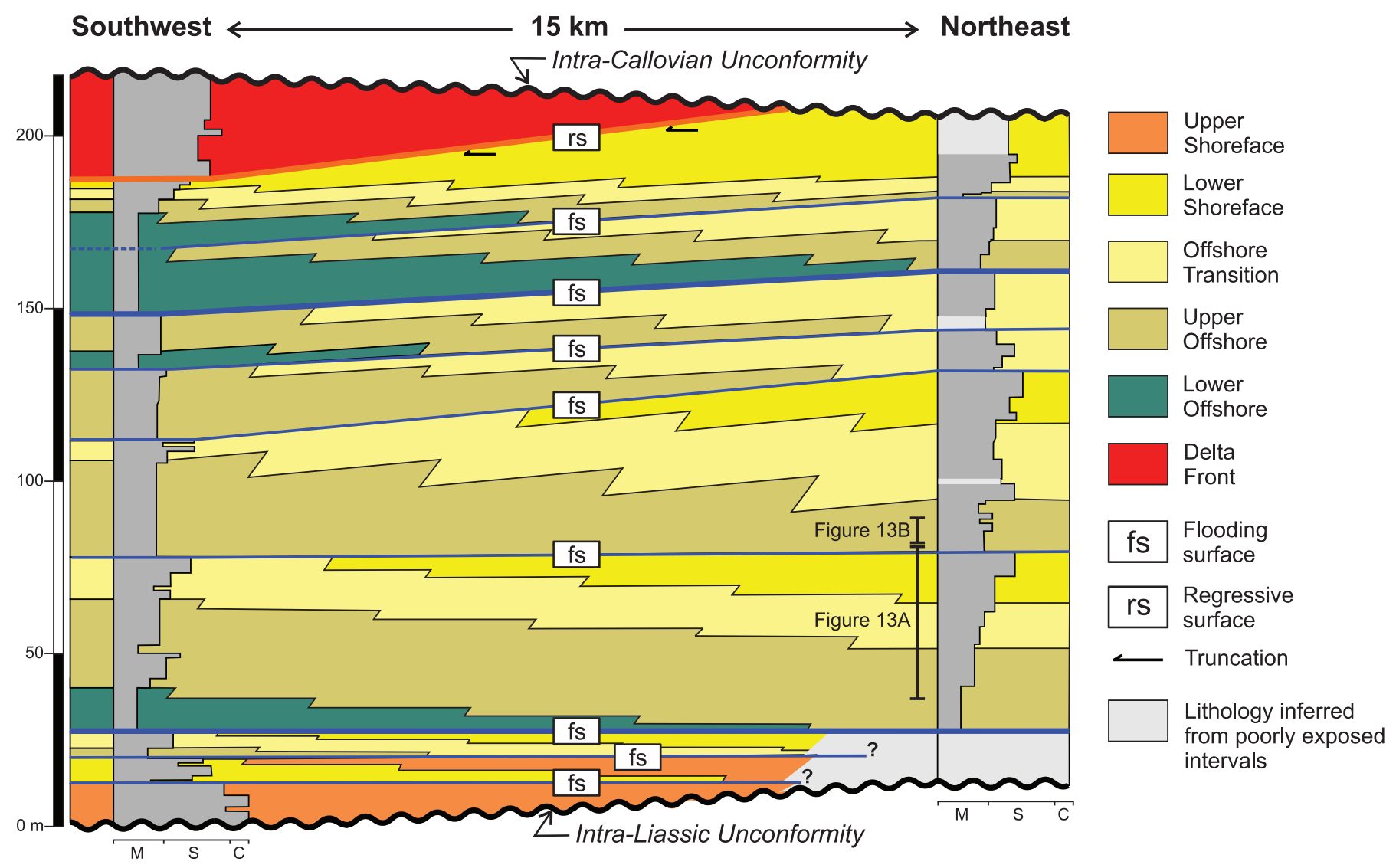

FIG. 11.- Simplified outcrop sections with spatial relationships of facies associations and interpreted depositional systems. Surfaces that represent vertical abrupt deepening or shallowing of depositional systems (i.e., flooding and regressive surfaces) are also shown. M, mudstone; S, sandstone; C, conglomerate.

( $<30 \mathrm{~m}$ thick) exhibits a rapid vertical transition from upper-shoreface deposits at its base to lower-offshore deposits at the top. This basal parasequence set is interpreted to preserve a highly retrogradational stacking pattern (Fig. 14). Parasequence Set II contains two parasequences, which are the thickest recognized in this study (up to $50 \mathrm{~m}$ thick), and are both similarly composed of upper-offshore to lowershoreface deposits. This parasequence set suggests a relative balance between supply and accommodation creation, and therefore is attributed to aggradational conditions with minor retrogradation (Fig. 14). The overlying two parasequences constitute the Parasequence Set III and are markedly finer grained in the outcrop localities, as well as thinner $(<20 \mathrm{~m}$ thick) than the previously described (Figs. 11, 12), although in this case without evidence of erosion at their tops. This vertical stacking pattern suggests a persistent landward displacement of facies belts (Fig. 14). The following two parasequences (Parasequence Set IV) show an abrupt turnaround of shoreline trajectory and a significant seaward migration of facies belts. In this case, lower-shoreface conditions are even represented in the westernmost sections of the study outcrops (Fig. 12), which represented shallow settings only at the earliest stages of sedimentation. This set (about $30 \mathrm{~m}$ thick) is considered to reflect progradational conditions (Fig. 14).

The analysis of parasequence sets, that is to say, lateral and vertical organization of facies belts and their bounding surfaces, also provides indirect information on the transits of the shorelines through time, even if associated deposits such as foreshore and coastal-plain sediments are not preserved (Helland-Hansen and Gjelberg 1994; Helland-Hansen and Hampson 2009). Parasequence sets are thus equivalent to stacked clinoform sets, which in turn represent overall seaward- or landwarddirected shoreline trajectories (cf. Helland-Hansen and Hampson 2009).
In this context, Parasequence Sets I and III would represent a low-angle transgressive trajectory of a stacked shoreline system, whereas Parasequence Set II would reflect a high-angle landward trajectory (Fig. 14). In turn, Parasequence Set IV corresponds to a low-angle, ascending regressive trajectory that occurred after the maximum transgression was reached (Fig. 14).

Although parasequences (and therefore parasequence sets) were not recognized in the fluvio-deltaic deposits that represent the uppermost interval of the Cuyo succession, inference about shoreline trajectories can be equally proposed considering key stratigraphic surfaces and internal architecture. Parasequence Set IV is truncated across the study area by a regional erosional surface, which is associated with the onset of the late Bathonian-early Callovian fluvio-deltaic depositional system (Fig. 12). This deltaic system is interpreted here to have been formed during a time when the shoreline trajectory was persistently migrating not only basinward but also downward (Fig. 14). The preservation of these deltaic deposits in the downdip sectors of the study area is likely a combination of cannibalization during deltaic progradation and extensive erosion related to a younger basin-wide unconformity (the Intra-Callovian Unconformity, Veiga et al. 2011).

\section{DISCUSSION}

\section{The Cuyo Sequence and Controls on Long-Term Evolution}

The anatomy and architecture of the Cuyo Group provides useful information for analyzing the main external factors that control the process and architecture of the early post-rift shallow-marine systems in central 

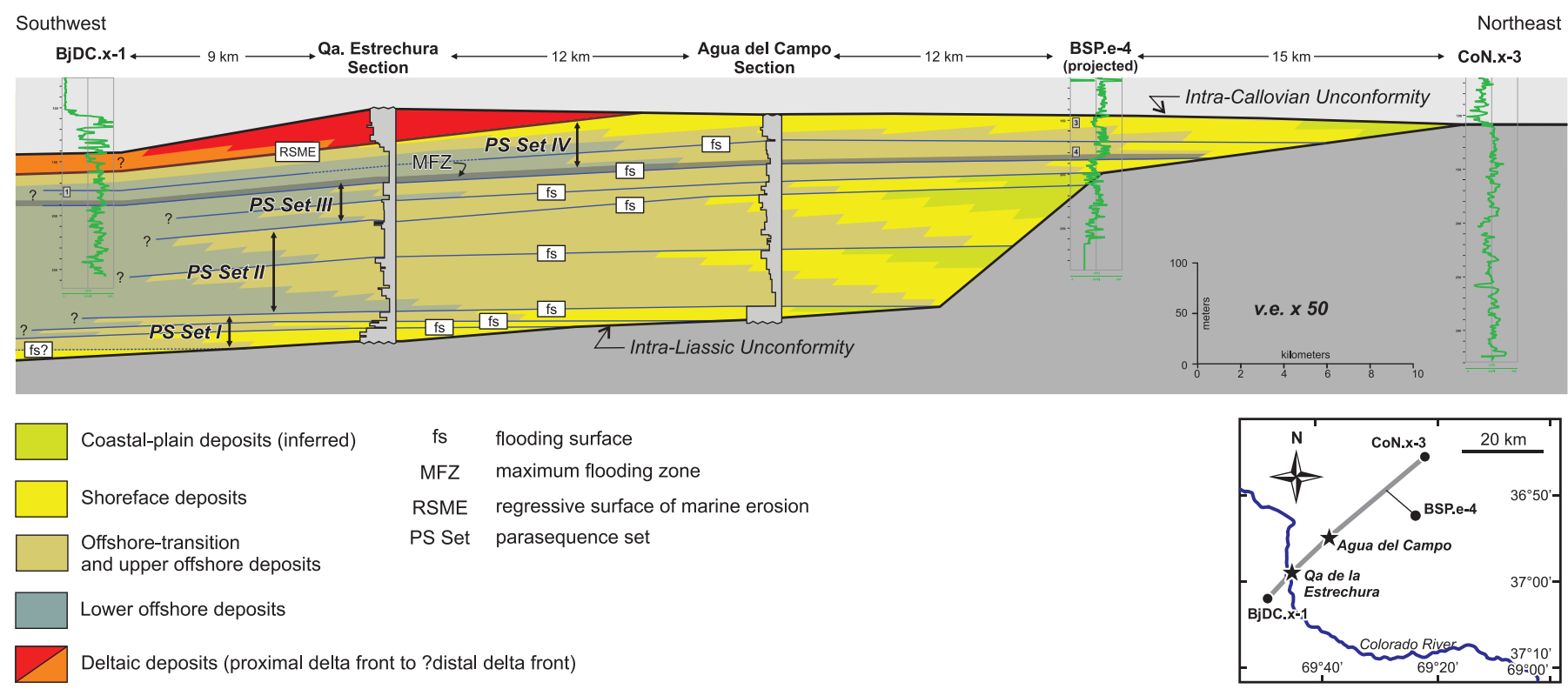

FIG. 12.-Depositional architecture of the study interval (combining outcrop and subsurface data), which shows the interpreted depositional environments across the study area, as well as key stratigraphic surfaces and parasequence sets.

Neuquén Basin. The Cuyo Group in the study area can be viewed as an entire depositional sequence limited by two basin-extensive sequence boundaries (Fig. 14). Using standard sequence-stratigraphic models (e.g., Van Wagoner et al. 1990; Plint and Nummedal 2000), this sequence is internally composed of a thick and long-lived transgressive systems tract (Parasequence Sets I to III), a relatively thin and shorter highstand systems tract (Parasequence Set IV), and a falling-stage systems tract (Fig. 14), which is solely preserved in down-dip portions of the region. The sequence extends from the late Toarcian to the early Callovian (Spalletti et al. 2012), covering about 11-15 My, and therefore should be considered a secondorder sequence. The unusually thick late Toarcian-early Bathonian TST of the Cuyo Sequence suggests persistent transgressive conditions, albeit alternating with aggrading stages, for up to $10 \mathrm{My}$ (Fig. 14). This fact indicates that accommodation creation largely exceeded sediment supply for the most part of the early post-rift evolution.

Most of the global Jurassic sea-level curves proposed suggest a more or less gradual sea-level rise from Pliensbachian to Bathonian times (Hallam 2001, and references therein). Therefore, this long-term sea-level rise certainly contributed to generate accommodation during early post-rift stages of the Neuquén Basin. On the other hand, the regressive pattern that is recognized all across the basin in the Bathonian (Legarreta and Uliana 1996), and is clearly expressed in the study area by a drastic change of depositional systems (Fig. 14), seems to be anomalous globally and might not be a eustatic event (Hallam 2001).

Regional subsidence related to thermal contraction of the lithosphere is a typical mechanism to create accommodation during the post-rift stage of a basin (McKenzie 1978), but its velocity can be variable trough time (e.g., Joy 1993; Gabrielsen et al. 2001; Dupré et al. 2007). In the Neuquén Basin, thermal subsidence probably started in the Early Jurassic (Uliana and Biddle 1988; Legarreta and Uliana 1996), but it contributed to create significant accommodation since the early Middle Jurassic (Cristallini et al. 2009, their fig. 2). Thus, regional thermal subsidence accounts for some of the accommodation space produced during the TST of the Cuyo Sequence.

An additional or alternative mechanism to create accommodation in a post-rift stage is associated with intermittent activity of syn-rift normal faults (i.e., mechanical subsidence). Syn-rift depressions and their overlying stratigraphic succession in the subsurface of the central
Neuquén Basin were recently seismically mapped in detail, aiming at assessing the role played by mechanical subsidence in Mesozoic-Cenozoic times (Cristallini et al. 2006, 2009). These studies did not recognize faultrelated accommodation associated with regional extension in Middle Jurassic strata. In contrast, they suggested that differences in compaction coefficients between the syn-rift deposits filling half-grabens (up to $3 \mathrm{~km}$ thick, locally) and the more rigid basement rocks located at the footwalls of normal faults produced differential subsidence. This differential compaction in conjunction with thermal subsidence created accommodation (Cristallini et al. 2006, 2009), a phenomenon that has been recognized in other post-rift successions (Færseth and Lien 2002). Evidence to suggest syn-depositional extensional faulting, such as progressive unconformities, has not been identified during our outcrop study, supporting the results of the large-scale subsurface studies.

In summary, it is proposed that accommodation associated with the thick TST of the post-rift Cuyo sequence was created by a combination of sea-level rise and thermal (regional) subsidence, which could have been locally amplified by differential compaction. The regional character of this relative sea-level rise (cf. Gawthorpe et al. 1994) is further supported by the fact that a similar large-scale transgressive pattern was reported for other Cuyo localities in central Neuquén Basin (Legarreta and Uliana 1996), for example in Chacay Melehue and Bardas Blancas regions (Fig. 1).

On the other hand, a long-term progradational-aggradational stacking pattern is recorded in southern sectors of the basin (Fig. 1), with deepmarine deposits grading into thick shallow-marine successions, eventually being capped by continental strata (Gulisano et al. 1984; Riccardi and Gulisano 1990; Arregui et al. 2011). This contrasting second-order stacking pattern recorded in the southern Neuquén Basin could reflect a similar relative sea-level rise, but coupled with large volumes of clastics delivered from hinterland areas (Legarreta and Uliana 1996).

\section{Controls on Parasequence Stacking}

The sequential development of the TST is characterized by three parasequence sets with particular features suggesting that the long-term transgression recorded in the Cuyo Sequence was not a uniform process and changes in the rate at which the transgression occurred can be 

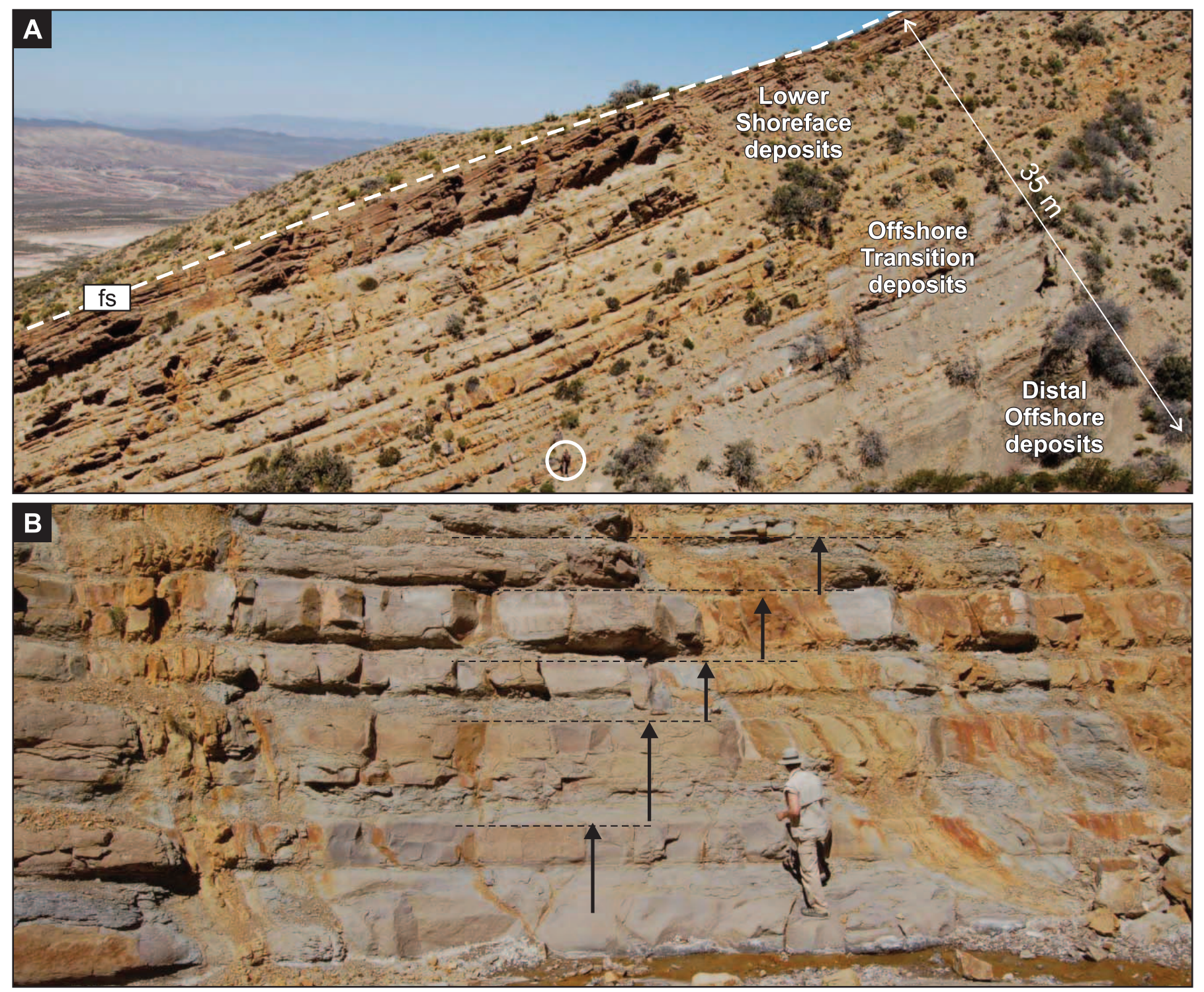

FIG. 13.-Attributes of the small-scale sequence stratigraphic units identified in the studied interval. A) General view of a parasequence showing the gradual transition from lower-offshore deposits to lower-shoreface facies. Person for scale. B) Detail view of small-scale cycles (arrows) defined by the alternation of muddy sandstones and sandy mudstones in an offshore-transition environment interpreted to represent bedsets.

identified (Figs. 12, 14). Two contrasting styles of retrogradational stacking were identified: a highly retrogradational stacking with relatively thin parasequences (Parasequence Sets I and III) and a mainly aggradational (slightly retrogradational) stacking dominated by relatively thick parasequences (Parasequence Set II).

Changes in the nature of the parasequence retrogradational stacking can be attributed to changes in the rate of accommodation creation due to relative sea-level rise (Van Wagoner et al. 1990; Howell and Flint 2003). However, if the thickness of individual parasequences is considered, an increase in the rate of relative sea-level rise will increase not only the overall rate of transgression but also the thickness of parasequences (Fig. 15B) (Myers and Milton 1996). In the same sense, a reduction in the rate of relative sea-level rise will slow down the transgression rate, but will also imply the development of thinner parasequences as the incremental rise in relative sea level is progressively smaller (Fig. 15B). Therefore, in order to explain the thinner parasequences during highly retrogradational intervals and thicker parasequences during mainly aggradational episodes identified in the Cuyo Group, other variables, acting independently or together with changes in relative sea level, should be considered.

Fluctuations in the rate of sediment delivered to a basin can produce changes in stacking patterns (Schlager 1993; Church and Gawthorpe 1997), and they would also have major implications in the accumulation rates, depositional styles, and resulting deposits. In this sense, a reduction in sediment supply during a constant relative sea-level rise could lead to an increase in the transgression rate, inasmuch as accommodation creation will be relatively greater and therefore amplifying the transgressive trend (Fig. 15C). On the contrary, an increase in the amount of sediment being delivered to the marine systems could counterbalance the effect of the constant relative sea-level rise. Under these circumstances, parasequences with a less retrogradational to even aggradational stacking pattern (i.e., lower transgression rates) could result, depending on the increment of sediment supplied (Fig. 15C). However, changes in sediment supply do not necessarily explain the observed changes in parasequence thickness, because this is a function of the rate of relative sea-level rise 


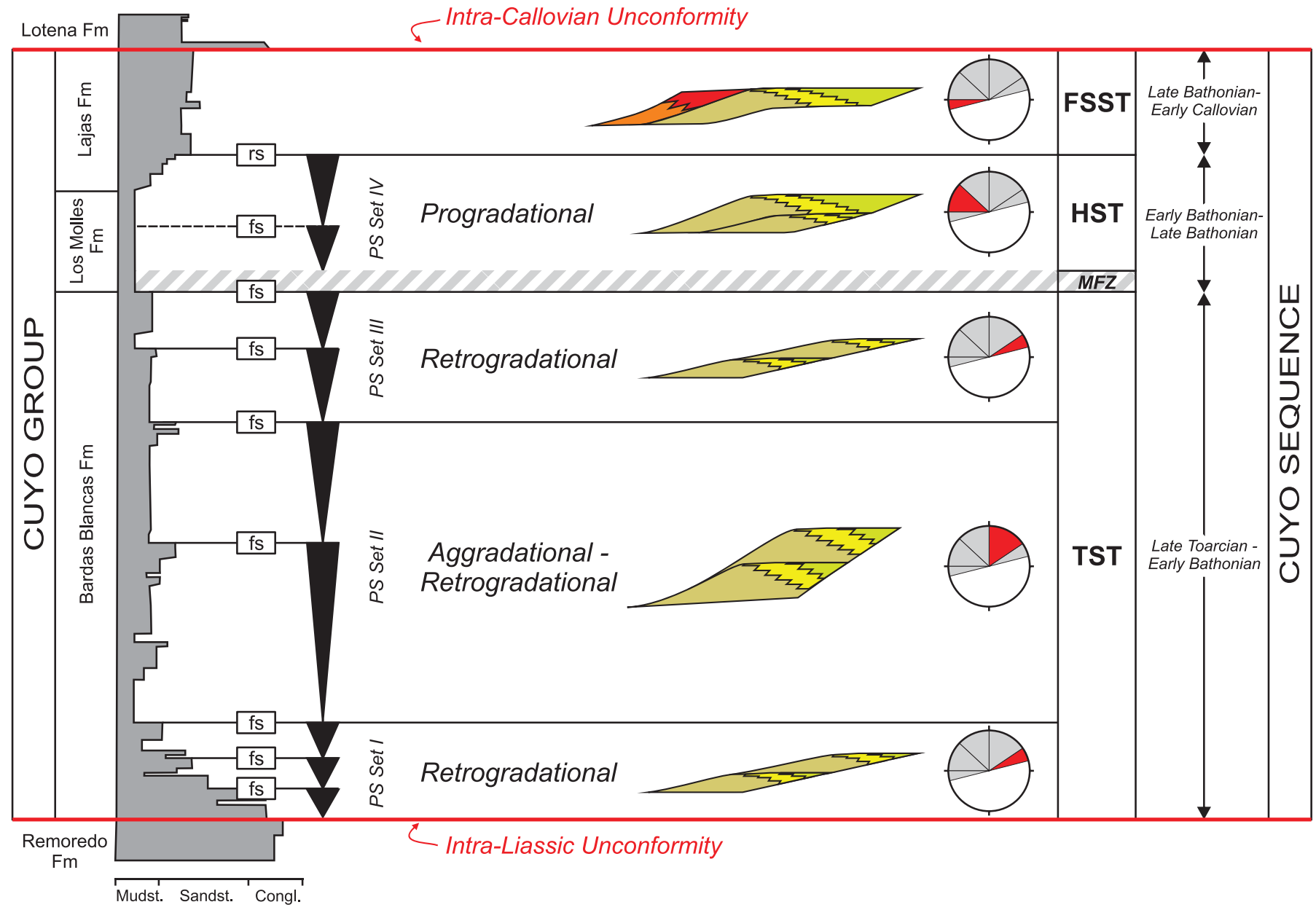

SHORELINE TRAJECTORIES

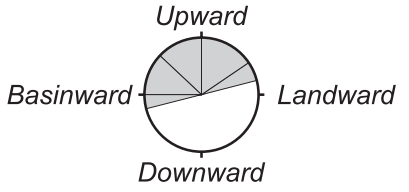

STRATIGRAPHIC SURFACES

\begin{tabular}{|c|c|}
\hline rs & Regressive Surface \\
\hline fs & Flooding Surface
\end{tabular}

SYSTEMS TRACTS

TST Transgressive Systems Tract

HST Highstand Systems Tract

FSST Falling Stage Systems Tract

\section{DEPOSITIONAL SYSTEMS}

Coastal Plain deposits

Shoreface deposits

Offshore-Transition and Offshore deposits

Proximal Delta Front deposits

Distal Delta Front Deposits

FIG. 14.-Sequence stratigraphic organization for the studied interval. The relationship between lithostratigraphic units, parasequences, parasequence sets, and systems tracts defined for the Cuyo Sequence is shown. The shoreline trajectories inferred for the studied interval are also presented.

(Myers and Milton 1996). Therefore, fluctuations in sediment supply alone could not account for the stacking-pattern changes observed in the TST of the Cuyo Sequence, at least at the large-scale, long-term evolution.

Consequently, in order to obtain the changes in the sequential architecture recorded in the studied long-term transgressive scenario a simultaneous change in both the rate of relative sea-level rise and sediment supply should be invoked. This means that to change to a more aggradational stacking but composed of thicker parasequences (transition from Parasequence Sets I to II) an increase in the rate of relative sea-level rise is needed (to obtain thicker parasequences) but coupled with an increase in sediment supply (to reduce the transgression rate). Quite the opposite, to explain the transition from Parasequence Set II to Parasequence Set III (a change to thinner parasequences but with a more pronounced transgressive stacking), a simultaneous reduction of the rate of relative sea-level rise and an even greater reduction in sediment supply is required. However, the synchronized increment (or reduction) in these two controlling factors is very unlikely to occur, inasmuch as many 


\section{A) ALL PARAMETERS CONSTANT}

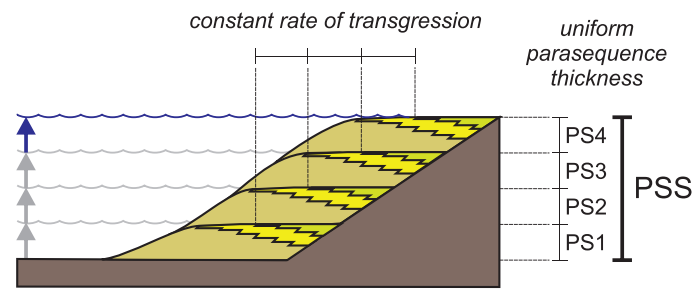

\section{REFERENCES}

\section{Depositional Systems}

$\square$ Coastal Plain deposits

Shoreface deposits

Offshore-Transition and Offshore deposits

Sequence Stratigraphic Units

PS Parasequence

PSS Parasequence Set
Transitions Analysis

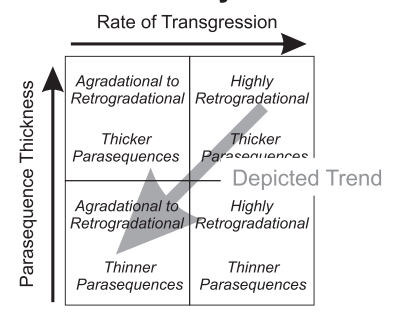

\section{B) CHANGES IN RATE OF RSL RISE}

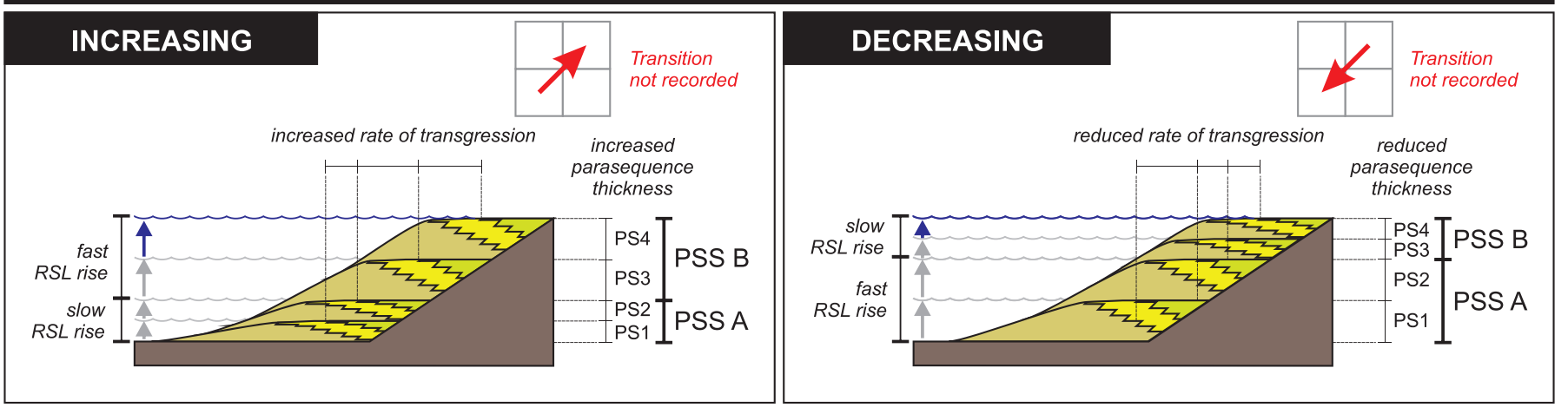

\section{C) CHANGES IN SEDIMENT SUPPLY}

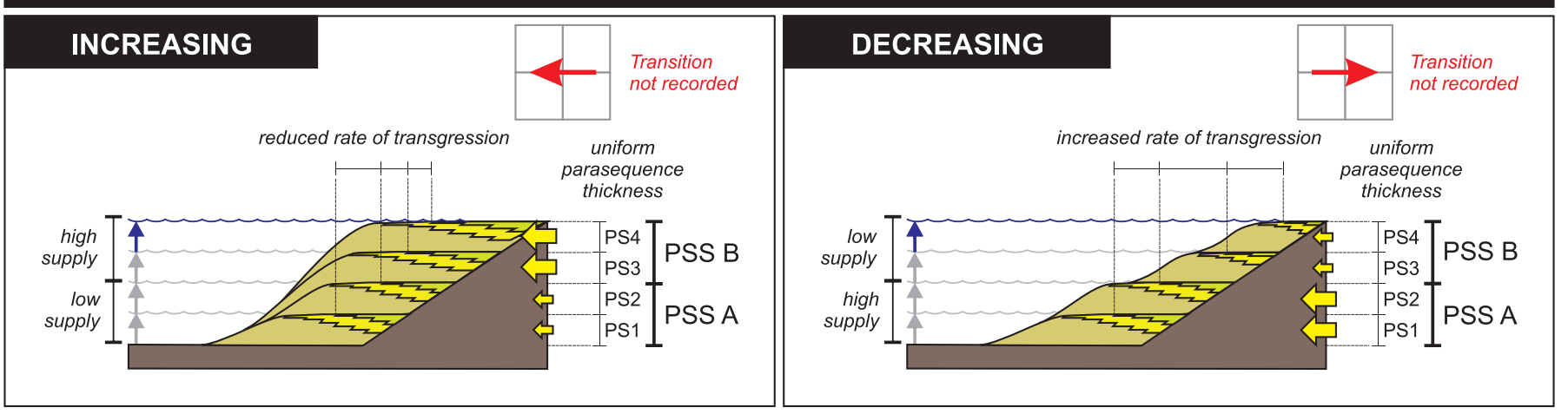

\section{D) CHANGES IN GRADIENT OF TOPOGRAPHY BEING FLOODED}
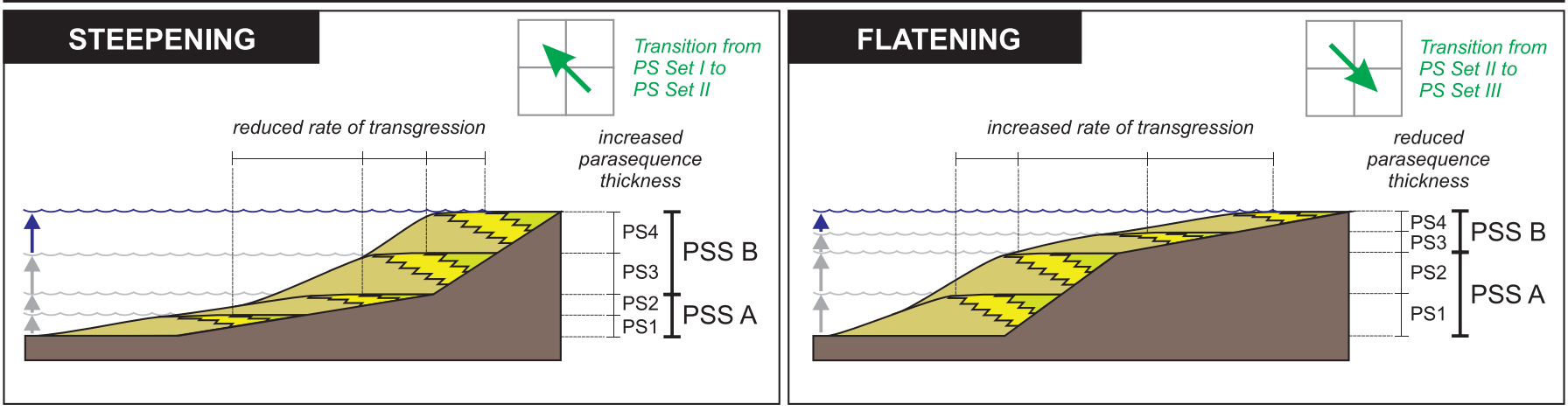

FIG. 15.-Potential transitions on parasequence stacking pattern to be developed during a long-term transgression as a consequence of changes in external forcing factors. A) No change as all parameters remain constant. B) Transitions observed due to changes in the rate of relative sea-level rise. C) Transitions observed related to changes in sediment supply. D) Transitions associated with changes in the gradient of the topography being flooded. 
authors have pointed that sediment supply to the deeper portions of the shallow marine systems will be considerably reduced during more transgressive conditions and vice versa (Loutit et al. 1988; Catuneanu 2006).

An alternative key factor that should be considered during transgressions is the physiography of the relief being flooded, because changes in its gradient can result in important fluctuations in the rate of transgression and even in the thickness of the resulting transgressive deposits (Cattaneo and Steel 2003). Examples of significant variations in the rate of transgression have been documented during the infill of terraced incised and inherited valleys (Rodriguez et al. 2005; Schwarz et al. 2011). The influence of a complex topography is particularly important in early postrift times because major structural features inherited from the syn-rift may exert a great influence in the development of early post-rift depositional systems. These major structural features typically produce a subtle terraced relief derived from relatively steep footwall scarps and flatter shoulders of original syn-rift fault-blocks (Gabrielsen et al. 2001; Færseth and Lien 2002; Zachariah et al. 2009a, 2009b).

Important changes in thickness over relatively short distances have been recorded for the early post-rift strata of the Cuyo Group (Figs. 3, 12), suggesting an inherited physiography from the syn-rift stage. Therefore, the combination of parasequence stacking patterns and thickness changes observed in the TST of the Cuyo Sequence could be the resulting stratigraphic record of a terraced relief being transgressed. In this context, the change from a highly retrogradational stacking pattern to an aggradational pattern (transition from Parasequence Sets I to II) could be attained by an increase in the gradient of the flooded relief (Fig. 15D). This would not only reduce considerably the rate of transgression but also result in an increase in the rate of relative sealevel rise, producing an increase in the thickness of individual parasequences. On the contrary, the renewed highly retrogradational conditions (Parasequence Set III) could be associated with a flattening of the topography (i.e., flooding a footwall crest?), increasing the net transgression rate, and reducing the individual thickness of parasequences (Fig. 15D).

\section{Towards a Model for Early Post-Rift Infill of Rift Depressions in the Neuquén Basin}

The integration of the results obtained in this study, together with regional information of the early post-rift deposits in central Neuquén Basin, allowed a model of how early post-rift sedimentary architecture is related to original syn-rift structures to be developed. The study area is dominated by shallow marine sedimentation, and the early post-rift succession is relatively thin $(300 \mathrm{~m})$ compared to more distal areas (e.g., in Chacay Melehue it is three times thicker, Fig. 2). Also, the timing of the transgression in the study area differs from more central parts of the basin, where deposition during the early post-rift transgression started as early as in the Pliesbachian, several My earlier than the late Toarcian times recorded in the study area. This indicates that the Pliensbachian early post-rift transgression of the Neuquén Basin started filling deep depocenters, and it was not until the late Toarcian that it reached topographically higher areas like the one studied here.

Considering that mechanically related subsidence was not recorded in the area and accommodation was largely created by a long-term relative sea-level rise (thermal subsidence + eustasy), it has to be assumed that most of the topographic relief that was flooded during the TST of the Cuyo Sequence was created during the syn-rift stage and filled passively during the long-term transgressive event. This also suggests that during the transgression most of the relief was flooded, generating a complex seafloor physiography that was gradually filled, which may have in turn affected ocean currents and the sediment routing pathways to the deeper parts of the depocenters.
The passive early post-rift infill of topography generated during syn-rift stages has been widely identified in other rifts systems (e.g., in the Northern North Sea and Norwegian Sea, Gabrielsen et al. 2001; Færseth and Lien 2002; Zachariah et al. 2009a, 2009b). Therefore, it is possible to assume that a large-scale geometry of deep basins and terraced platforms could have been formed during the syn-rift stage of the Neuquén Basin, which controlled the anatomy and internal arrangement of the early postrift succession in this part of the basin. This might also have implications for understanding the real dimensions of the depocenters generated during the syn-rift stage, generally considered to be relatively small, but probably with limited distribution of their deposits, because they could have been considerably underfilled when the onset of thermal subsidence and the transition to the early post-rift occurred.

Finally, high-frequency cycles (parasequences), parasequence sets, and a second-order sequence with a long-lived and thick $(250 \mathrm{~m})$ TST were documented in the Cuyo succession. However, intermediate-scale sequences (e.g., $\sim 100 \mathrm{~m}$ thick) were not identified within this TST due to the lack of clear evidence such as surfaces indicating regressive episodes that can be interpreted as sequence boundaries and/or progradational parasequence patterns suggesting the development of intermediate-scale HSTs. Regarding sequence-stratigraphic templates for the early post-rift of the Neuquén Basin (and equivalent conditions worldwide), it is important to consider that these intermediate-scale sequences could be most likely subdued due to the particular set of conditions controlling this low-order TST. In the case of the Neuquén Basin, detailed high-resolution sequence-stratigraphic studies integrating information from the study area and the distal sectors of the basin (where sequence boundaries and lowstand deposits might be more evident) would be necessary to fill this gap.

\section{CONCLUSIONS}

1. By integrating facies associations and sequence-stratigraphic analysis from outcrops and cores, this study has documented the anatomy and sequence architecture of the early post-rift in the eastcentral Neuquén Basin (Middle Jurassic, Cuyo Group).

2. Two contrasting marine depositional systems are represented in the Cuyo Group through time. A storm- and wave-dominated shoreface-offshore depositional system developed from the late Toarcian to the early Bathonian. This long-lived system was eventually replaced by a fluvio-deltaic depositional system (late Bathonianearly Callovian). Despite differences in depositional styles, both systems deepen toward the west.

3. Regressive high-frequency cycles (from 7 to $50 \mathrm{~m}$ ) bounded by marine flooding surfaces (i.e., parasequences) were recognized in the Toarcian-Bathonian depositional system. Transgression-related erosion at the top of parasequences was uncommon and mostly developed onto shoreface deposits.

4. Four parasequences sets were defined within the Cuyo Group, and this allowed the reconstruction of shoreline trajectories throughout the early post-rift accumulation. The lower three sets represent long-lived transgressive conditions, but with different rates of retrogradation (from high to very low). The youngest one indicates a turnaround to normal progradational conditions. A forced regressive event with no parasequence development but showing an abrupt shift of depositional systems characterizes the upper part of the succession.

5. The long-term transgressive trend recorded in the study area is interpreted to represent the combination of an overall low sediment supply and a relative sea-level rise, promoted by a combination of a global eustatic rise and thermal subsidence (locally combined with differential compaction between syn-rift sequences and basement rocks).

6. The large-scale wedge shape of the Cuyo Sequence and the drastic changes in parasequence stacking patterns recorded during the TST 
are attributed to represent the result of the long-term flooding of an inherited, terraced topography of syn-rift structures.

7. A large-scale geometry of basins and platforms, created during the syn-rift stage and passively filled during the early post-rift is interpreted for this part of the basin. That would account for the differences in thickness of the post-rift succession as well as the different timing of the initial deposits of the Cuyo Sequence in relatively close areas.

\section{ACKNOWLEDGMENTS}

We gratefully acknowledge the management of YPF S.A. for permission to publish this article, as well as for providing subsurface data and financial support through a Cooperation Agreement between YPF and the UNLP. L.A. Buatois (University of Saskatchewan, Canada) is thanked for helping with the identification of trace fossils in core. L. D'Elía and A. Piqué are acknowledged for field assistance. D. Hodgson and Associate Editor P. Burgess provided useful comments to improve the original version of this manuscript.

\section{REFERENCES}

ARnotT, R.W.C., AND HAND, B.M., 1989, Bedforms, primary structures and grain fabric in the presence of suspended sediment rain: Journal of Sedimentary Petrology, v. 59, p. $1062-1069$.

Arregui, C., Carbone, O., and Martínez, R., 2011, El Grupo Cuyo (Jurásico Temprano-Medio) en la Cuenca Neuquina: Geología y Recursos Naturales de la Provincia del Neuquén, in Relatorio XVIII Congreso Geológico Argentino, p. 77-89.

Bhattacharya, J.P., and Walker, R.G., 1992, Deltas, in Walker, R.G., and James, N.P., eds., Facies Models, Response to Sea Level Change: Geological Association of Canada, p. 157-178.

Bromley, R.G., 1996, Trace Fossils: Biology, Taphonomy and Applications: London, Chapman \& Hall, 361 p.

Burgess, P.M., Flint, S.S., And Johnson, S., 2000, Sequence stratigraphic interpretation of turbiditic strata: an example from Jurassic strata of the Neuquén basin, Argentina: Geological Society of America, Bulletin, v. 112, p. 1650-1666.

Cattaneo, A., and Steel, R.J., 2003, Transgressive deposits: a review of their variability: Earth-Science Reviews, v. 62, p. 187-228.

Catuneanu, O., 2006, Principles of Sequence Stratigraphy: Amsterdam, Elsevier, 371 p.

Church, K.D. and Gawthorpe, R.L., 1997, Sediment supply as a control on the variability of sequences: an example from the late Namurian of northern England: Geological Society of London, Journal, v. 154, p. 55-60.

Clifton, H.E., 1973, Pebble segregation and bed lenticularity in wave-worked versus alluvial gravel: Sedimentology, v. 20, p. 173-187.

Clifton, H.E., 2003, Supply, segregation, successions, and significance of shallow marine conglomeratic deposits: Bulletin of Canadian Petroleum Geology, v. 51, p. 370-388.

Clifton, E.H., 2006, A re-examination of facies models for clastic shorelines, in Posamentier, H.W., and Walker, R.G., eds., Facies Models Revisited: SEPM, Special Publication 84, p. 293-337.

Copestake, P., Sims, A.P., Crittenden, S., Hamar, G.P., Ineson, J.R., Rose, P.T., and Tringham, M.E., 2003, Lower Cretaceous, in Evans, D., Graham, C., Armour, A., and Bathurst, P., eds, The Millennium Atlas: Petroleum Geology of the Central and Northern North Sea: Geological Society of London , p. 191-211.

Cristallini, E.O., Bottesi, G., Gavarrino, A., Rodriguez, L., Tomezzoli, R.N., and Comeron, R. 2006, Synrift geometry of the Neuquén Basin in the northeastern Neuquén Province, Argentina, in Kay, S.M., and Ramos, V.A., eds., Evolution of the Andean margin: A Tectonic and Magmatic View from the Andes to the Neuquén Basin $\left(35^{\circ}-39^{\circ} \mathrm{S}\right.$ lat): Geological Society of America, Special Paper 407, p. $147-161$.

Cristallini, E., Tomezzoli, R., Pando, G., Gazzera, C., Martínez, J.M., Quiroga, J., Buhler, M., Bechis, F., Barredo, S., and Zambrano, O., 2009, Controles Precuyanos en la estructura de la Cuenca Neuquina: Asociación Geológica Argentina, Revista, v. 65 , p. $248-264$.

Cruz, C.E., Robles, F., Sylwan, C.A., And Villar, H., 1999, Los sistemas petroleros jurásicos de la Dorsal de Huincul, Cuenca Neuquina, Argentina: IV Congreso Exploración y Desarrollo de Hidrocarburos, Actas I, p. 177-195.

Dellapé, D.A., Mombrú, C., Pando, G.A., Riccardi, A.C., Uliana, M.A., and WestermanN, G.E.G., 1978, Edad y correlación de la Formación Tábanos en Chacay Melehue y otras localidades de Neuquén y Mendoza. Con consideraciones sobre la distribución y significado de las sedimentitas lotenianas: Obra Centenario Museo de La Plata, Paleontología 5, p. 81-105.

DotT, R.H., AND BouRgeols, J., 1982, Hummocky stratification: significance of its variable bedding sequences: Geological Society of America, Bulletin, v. 93, p. 663-680.

Doyle, P., Poiré, D., Spalletti, L., Pirrie, D., Brenchley, P., and Matheos, S., 2005, Relative oxygenation of the Tithonian-Valanginian Vaca Muerta-Chachao formations of the Mendoza Shelf, Neuquén Basin, Argentina, in Veiga, G., Spalletti, L.,
Howell, J., and Schwarz, E., eds., The Neuquén Basin: A Case Study in Sequence Stratigraphy and Basin Dynamics: Geological Society of London, Special Publication 252, p. $185-206$.

Dupré, S., Bertotti, G., And Cloetingh, S., 2007, Tectonic history along the South Gabon Basin: anomalous early post-rift subsidence: Marine and Petroleum Geology, v. 24 , p. $151-172$.

Fielding, C.R., 2010, Planform and facies variability in asymmetric deltas: facies analysis and depositional architecture of the Turonian Ferron Sandstone in the western Henry Mountains, south-central Utah, U.S.A.: Journal of Sedimentary Research, v. 80, p. 455-479.

F freseth, R.B., And Lien, T., 2002, Cretaceous evolution in the Norwegian Sea: a period characterized by tectonic quiescence: Marine and Petroleum Geology, v. 19, p. $1005-1027$.

Franzese, J.R., And Spalletti, L.A., 2001, Late Triassic-early Jurassic continental extension in southwestern Gondwana: tectonic segmentation and pre-break-up rifting: Journal of South American Earth Sciences, v. 14, p. 257-270.

Franzese, J., Veiga, G.D., Schwarz, E., and Gómez-Pérez, I., 2006, Tectonostratigraphic evolution of a Mesozoic rift border system: the Chachil depocentre, southern Neuquén Basin, Argentina: Geological Society of London, Journal, v. 163, p. $707-721$.

Frey, R.W., and Pemberton, S.G., 1984, Trace fossil facies models, in Walker, R.G., ed., Facies Models, Second Edition: Geoscience Canada, p. 189-207.

Gabrielsen, R.H., Kyrkjeb, R., Faleide, J.I., Fjeldskaar, W., and KJennerud, T. 2001, The Cretaceous post-rift basin configuration of the northern North Sea: Petroleum Geoscience, v. 7, p. 137-154.

Gawthorpe, R.L., Frasier, A.J., and Collier, R.E.L., 1994, Sequence stratigraphy in active extensional basins: implications for the interpretation of ancient basin fills: Marine and Petroleum Geology, v. 11, p. 642-658.

Gulisano, C.A., 1981, El Ciclo Cuyano en el norte del Neuquén y sur de Mendoza: 8 Congreso Geológico Argentino, Buenos Aires, Actas 3, p. 579-592.

Gulisano, C.A., And Gutiérrez Pleimling, A.R., 1994, The Jurassic of the Neuquén Basin, a) Neuquén Province: Buenos Aires, Asociación Geológica Argentina, Serie E2, $111 \mathrm{p}$.

Gulisano, C.A., Gutiérrez Pleimling, A.R., and Digregorio, R.E., 1984, Esquema estratigráfico de la secuencia jurásica del oeste de la provincia del Neuquén: IX Congreso Geológico Argentino, S.C. de Bariloche, Actas I, p. 236259.

Hallam, A., 2001, A review of the broad pattern of Jurassic sea-level changes and their possible causes in the light of current knowledge: Palaeogeography, Palaeoclimatology, Palaeoecology, v. 167, p. 23-37.

Hampson, G.J., Gani, M.R, Sharman, K.F., Irfan, N., and Bracken, B., 2011, Alongstrike and down-dip variations in shallow-marine sequence stratigraphic architecture: Upper Cretaceous Star Point Sandstone, Wasatch Plateau, Central Utah, U.S.A Journal of Sedimentary Research, v. 81, p. 159-184.

Harms, J.C., Southard, J.B., Spearing, D.R., and Walker, R.G., 1975, Depositional Environments as Interpreted from Primary Sedimentary Structures and Stratification Sequences: SEPM, Short Course 2, $161 \mathrm{p}$.

Hart, R.S., AND Plint, A.G., 1995, Gravelly shoreface and beachface deposits, in Plint, A.G., ed., Sedimentary Facies Analysis: A Tribute to the Research and Teaching of Harold G. Reading: International Association of Sedimentologists, Special Publication 22 , p. $75-100$.

Helland-Hansen, W., and Gjelberg, J.G., 1994, Conceptual basis and variability in sequence stratigraphy: a different perspective: Sedimentary Geology, v. 92, p. 3152 .

Helland-Hansen, W., and Hampson, G.J., 2009, Trajectory analysis: concepts and applications: Basin Research, v. 21, p. 454 483.

Howell, J.A., And Flint, S.S., 2003, The parasequences of the Book Cliffs, in Coe, A.L., ed., The Sedimentary Record of Sea-Level Change: Cambridge, U.K., Cambridge University Press, p. 158-178.

Howell, J., Schwarz, E., Spalletti, L., And Veiga, G., 2005, The Neuquén Basin: an overview, in Veiga, G., Spalletti, L., Howell, J., and Schwarz, E., eds., The Neuquén Basin: A Case Study in Sequence Stratigraphy and Basin Dynamics: Geological Society of London, Special Publication 252, p. 1-14.

Howell, J.A., Vassel, A., AND Aune, T., 2008, Modelling of dipping clinoform barriers within deltaic outcrops, analogues from the Cretaceous Western Interior Basin, USA, in Robinson, A., Griffiths, P., Price, S., Hegre, J., and Muggeridge, A., eds., The Future of Geological Modelling in Hydrocarbon Development: Geological Society of London, Special Publication 309, p. 99-121.

JoY, A.M., 1993, Comments on the pattern of post-rift subsidence in the Central and Northern North Sea Basin, in Williams, G.D., and Dobba, A., eds., Tectonics and Seismic Sequence Stratigraphy: Geological Society of London, Special Publication 71 p. $123-140$.

Legarreta, L., And Uliana, M.A., 1991, Jurassic-Cretaceous marine oscillations and geometry of back arc basin fill, Central Argentine Andes, in Macdonald, D.I.M., ed., Sedimentation, Tectonics and Eustasy: Sea-Level Changes at Active Margins: International Association of Sedimentologists, Special Publication 12, p. 429-450.

Legarreta L, and Uliana, M.A., 1996, The Jurassic succession in west-central Argentina: stratal patterns, sequences and paleogeographic evolution: Palaeogeography, Palaeoclimatology, Palaeoecology, v. 120, p. 303-330.

Legarreta, L., and Villar, H.J., 2011, Geological and Geochemical Keys of the Potential Shale Resources, Argentina Basins: Search and Discovery Article \#80196. 
Loutit, T.S., Hardenbol, J., Vail, P.R., and Baum, G.R.,1988, Condensed sections: the key to age determination and correlation of continental margin sequences, in Wilgus, C.K., Hastings, B.S., Kendall, C.G.St.C., Posamentier, H.W., Ross, C.A., and Van Wagoner, J.C., eds., Sea-Level Changes: An Integrated Approach: SEPM, Special Publication 42, p. 183-213.

MacEachern, J.A., AND BAnN, K.L., 2008, The role of ichnology in refining shallow marine facies models, in Hampson, G.J., Steel, R.J., Burgess, P.M., and Dalrymple, R.W., eds., Recent Advances in Models of Siliciclastic Shallow-Marine Stratigraphy: SEPM, Special Publication 90, p. 73-116.

MacEachern, J.A., And Pemberton, S.G., 1992, Ichnological aspects of Cretaceous shoreface successions and shoreface variability in the Western Interior Seaway of North America, in Pemberton, S.G., ed., Applications of Ichnology to Petroleum Exploration: a Core Workshop: SEPM, Core Workshop 17, p. 169-198.

MacEachern, J.A., Bann, K.L., Bhattacharya, J.P., and Howell, C.D., Jr., 2005, Ichnology of deltas: organism responses to the dynamic interplay of rivers, waves, storms, and tides, in Bhattacharya, J.P., and Giosan, L., eds., River DeltasConcepts, Models, and Examples: SEPM, Special Publication 83, p. 49-85.

MacEachern, J.A., Pemberton, S.G., and Bhattacharya, J.P., 2007, Departures from archetypal ichnofacies: effective recognition of environmental stress in the rock record, in MacEachern, J.A., Bann, K.L., Gingras, M.K., and Pemberton, S.G., eds., Applied Ichnology: SEPM, Short Course Notes 52, p. 65-93.

Martin, K.D., 2004, A re-evaluation of the relationship between trace fossils and dysoxia, in McIlroy, D., ed., The Application of Ichnology to Palaeoenvironmental and Stratigraphic Analysis: Geological Society of London, Special Publications 228, p. $141-156$.

McKenzie, D., 1978, Some remarks on the development of sedimentary basins: Earth and Planetary Science Letters, v. 40, p. 25-32.

Meyers, P.A., 2006, Paleoceanographic and paleoclimatic similarities between Mediterranean sapropels and Cretaceous black shales: Palaeogeography, Palaeoclimatology, Palaeoecology, v. 235, p. 305-320.

Morris, J.E., Hampson, G.J., AND Johnson, H.D., 2006, A sequence stratigraphic model for an intensely bioturbated shallow-marine sandstone: the Bridport Sand Formation, Wessex Basin, UK: Sedimentology, v. 53, p. 1229-1263.

Mulder, T., Syvitski, J.P.M., Migeon, S., Faugéres, J.C., and Savoye, B., 2003, Marine hyperpycnal flows: initiation, behavior and related deposits. A review: Marine and Petroleum Geology, v. 20, p. 861-882.

Muravchick, M., D'elia, L., Bilmes, A., And Franzese, J.R., 2011, Syn-eruptive/intereruptive relations in the syn-rift deposits of the Precuyano Cycle, Sierra de Chacaico, Neuquén Basin, Argentina: Sedimentary Geology, v. 238, p. 132-144.

Myers, K.J., And Milton, N.J., 1996, Concepts and principles of sequence stratigraphy, in Emery, D., and Myers, K.J., eds., Sequence Stratigraphy: Oxford, U.K., Blackwell Science, p. 11-41.

Nøttvedt, A., Gabrielsen, R.H., and Steel, R.J., 1995, Tectono-stratigraphy and sedimentary architecture of rift basins, with reference to the northern North Sea: Marine and Petroleum Geology, v. 12, p. 881-901.

Pemberton, S.G., MacEachern, J.A., and Frey, R.W., 1992, Trace fossil facies models: environmental and allostratigraphic significance, in Walker, R.G., and James, N.P., eds., Facies Models: Response to Sea-Level Change: Geological Association of Canada, p. 47-72.

Plint, A.G., And Nummedal, D., 2000, The falling stage systems tract: recognition and importance in sequence stratigraphic analysis, in Hunt, D., and Gawthorpe, R.L., eds., Sedimentary Responses to Forced Regressions: Geological Society of London, Special Publication 172, p. 1-17.

Plint, A.G., Tyagi, A., Hay, M.J., Varban, B.L., Zhang, H., and Roca, X., 2009 , Clinoforms, paleobathymetry, and mud dispersal across the Western Canada Cretaceous Foreland Basin: evidence from the Cenomanian Dunvegan Formation and contiguous strata: Journal of Sedimentary Research, v. 79, p. 144-161.

Reading, H.G., and Collinson, J.D., 1996, Clastic coasts, in Reading, H.G., ed., Sedimentary Environments; Processes, Facies and Stratigraphy: Oxford, U.K., Blackwell Science, p. 232-280.

Riccardi, A.C., 2008, El Jurásico de la Argentina y sus Amonites: Asociación Geológica Argentina, Revista, v. 63, p. 625-643.

Riccardi, A.C., AND Gulisano, C.A., 1990, Unidades Limitadas por Discontinuidades. Su aplicación al Jurásico andino: Asociación Geológica Argentina, Revista, v. 45, p. 346-364.

Rodríguez, A., Anderson, J.B., And Simms, A.R., 2005, Terrace inundation as an autocyclic mechanism for parasequence formation: Galveston Estuary, Texas, U.S.A: Journal of Sedimentary Research, v. 75, p. 608-620.

Schatz, W., 2005, Palaeoecology of the Triassic black shale bivalve Daonella: new insights into an old controversy: Palaeogeography, Palaeoclimatology, Palaeoecology, v. 216, p. 189-201.
Schlager, W., 1993, Accommodation and supply: a dual control on stratigraphic sequences: Sedimentary Geology, v. 86, p. 111-136.

Schulte, P., Scheibner, C., and Spejer, R.P., 2011, Fluvial discharge and sea-level changes controlling black shale deposition during the Paleocene-Eocene Thermal Maximum in the Dababiya Quarry section, Egypt: Chemical Geology, v. 285, p. 167183.

Schwarz, E., Veiga, G.D., Spalletti, L.A, and Massaferro, J.L., 2011, The transgressive infill of an inherited-valley system: the Springhill Formation (Lower Cretaceous) in southern Austral Basin, Argentina: Marine and Petroleum Geology, v. 28, p. $1218-1241$

Spalletti, L.A., Parent, H.P., Veiga, G.D., and Schwarz, E., 2012, Amonites y bioestratigrafía del Grupo Cuyo en la Sierra de Reyes (Cuenca Neuquina central, Argentina) y su significado secuencial: Andean Geology, v. 39, p. 464-481.

Storms, J.E.A., And Hampson, G.J., 2005, Mechanisms for forming discontinuity surfaces within shoreface-shelf parasequences: sea level, sediment supply or wave regime?: Journal of Sedimentary Research, v. 75, p. 67-81.

STow, A.V., 2007, Sedimentary Rocks in the Field: A Color Guide, Third Edition; Manson, $318 \mathrm{p}$.

SwIFT, D.J.P., 1968, Coastal erosion and transgressive stratigraphy: Journal of Geology, v. 76, p. $444-456$.

Uliana, M.A., and Biddle, K.T., 1988, Mesozoic-Cenozoic paleogeographic and geodynamic evolution of southern South America: Revista Brasilera de Geociencias, v. 18 , p. $172-190$.

VAN DEN BERGH, T.C.V., AND GARRISON, J.R., JR., 2004, The geometry, architecture, and sedimentology of fluvial and deltaic sandstones within the Upper Ferron Sandstone Last Chance Delta: implications for reservoir modeling, in Chidsey, T.C., Adams, R.D., and Morris, T.H., eds., Regional to Wellbore Analog for Fluvial-Deltaic Reservoir Modelling: The Ferron Sandstone of Utah: American Association of Petroleum Geologists, Studies in Geology 50, p. 451-498.

Van Wagoner, J.C., Posamentier, H.W., Mitchum, R., Vail, P.R., Sarg, J.F., Loutit, T.S., And Hardenbol, J., 1988, An overview of the fundamentals of sequence stratigraphy and key definitions, in Wilgus, C.K., Hastings, B.S., Kendall, C.G.St.C., Posamentier, H.W., Ross, C.A., and Van Wagoner, J.C., eds., Sea-Level Changes: An Integrated Approach: SEPM, Special Publication 42, p. 39-45.

Van Wagoner, J.C., Mitchum, R.M., Campion, K.M., and Rahmanian, V.D., 1990, Siliciclastic Sequence Stratigraphy in Well Logs, Cores, and Outcrop: Concepts for High-Resolution Correlation of Time and Facies: American Association of Petroleum Geologists, Methods in Exploration Series, 7, 255 p.

Varban, B.L., and Plint, A.G., 2008, Sequence stacking patterns in the Western Canada foredeep: influence of tectonics, sediment loading and eustasy on deposition of the Upper Cretaceous Kaskapau and Cardium Formations: Sedimentology, v. 55, p. $395-421$.

Vergani, G.D., Tankard, A.J., Belotti, H.J., and Welsink, H.J., 1995, Tectonic evolution and paleogeography of the Neuquen Basin, Argentina, in Tankard, A.J., Suarez Soruco, R., and Welsink, H.J., eds., Petroleum Basins of South America: American Association of Petroleum Geologists, Memoir 62, p. 383-402.

Veiga, G.D., Schwarz, E., and Spalletti, L.A., 2011, Análisis estratigráfico de la Formación Lotena (Calloviano superior-Oxfordiano inferior) en la Cuenca Neuquina Central, República Argentina. Integración de información de afloramientos y subsuelo: Andean Geology, v. 38, p. 171-197.

Walker, R.G., And Plint, A.G., 1992, Wave- and storm-dominated shallow marine systems, in Walker, R.G., and James, N.P., eds., Facies Models: Response to Sea Level Change: Geological Association of Canada, p. 219-238.

Watcharanantakul, R., and Morley, C.K., 2000, Syn-rift and post-rift modelling of the Pattani Basin, Thailand: evidence for ramp-flat detachment: Marine and Petroleum Geology, v. 17, p. 937-958.

Zachariah, A.-J., Gawthorpe, R., and Dreyer, T., 2009a, Evolution and strike variability of early post-rift deep-marine depositional systems: Lower to MidCretaceous, North Viking Graben, Norwegian North Sea: Sedimentary Geology, v. 220 , p. $60-76$.

Zachariah, A.-J., Gawthorpe, R., Dreyer, T., and Corfield, S., 2009b, Controls on early post-rift physiography and stratigraphy, lower to mid-Cretaceous, North Viking Graben, Norwegian North Sea: Basin Research, v. 21, p. 189-208.

Zecchin, M., and Catuneanu, O., 2013, High-resolution sequence stratigraphy of clastic shelves I: units and bounding surfaces: Marine and Petroleum Geology, v. 39, p. $1-25$.

Received 9 August 2012; accepted 21 March 2013. 